\title{
ARE ACADEMIC FREEDOM AND FREE SPEECH \\ DEFENCES TO POISONED EDUCATIONAL ENVIRONMENT? - WHAT CAN ROSS TELL US ABOUT SEXUAL HARASSMENT?
}

\author{
SHIRISH P. CHOTALIA ${ }^{*}$
}

The author's goal is to examine the issues surrounding sexual harassment in the educational environment. Because education and research are so closely allied with freedom of expression, there will be inevitable conflicts whenever attempts are made to ensure a discrimination-free learning environment by limiting discriminatory expression. The author begins by surveying current Canadian and American jurisprudence on sexual harassment. She suggests that the Canadian test for sexual harassment should and will come to more closely parallel that in the U.S., where there is a far larger body of jurisprudence on the topic. Next, the author focuses on the Ross decision, currently on appeal to the Supreme Court of Canada. This case has raised many issues that are unique to discrimination in the educational context. The author then combines the concerns specific to sexual harassment and those unique to harassment in the educational setting. She notes that academic freedom is not opposed to, but is actually interdependant with "inclusivity" and provision of a discrimination-free educational environment. As a result, the right to academic freedom carries with it the duty to use that freedom honestly and without bias. In conclusion, the author proposes that academic freedom may be a defence to the creation of a poisoned educational environment through discrimination, but only where there is bona fide educational or research value to the impugned expression. With this goal in mind, the developing Canadian jurisprudence will have to strike a balance among the inherent tensions at play in these situations.
L'auteure examine les questions relatives au harcèlement sexuel en milieu éducatif. Parce que l'éducation et la recherche sont si étroitement liées à la liberté d'expression, des conflits inévitables surgissent chaque fois qu'on tente de combattre la discrimination en limitant l'expression discriminatoire. L'auteure survole d'abord la jurisprudence canadienne et américaine en matière de harcèlement sexuel. Elle suggère que les critères canadiens devraient éventuellement se rapprocher des critères américains, qui reposent sur un fonds jurisprudentiel beaucoup plus vaste sur le sujet. Puis, l'auteure se penche sur la décision Ross, présentement en instance d'appel devant la Cour suprême du Canada. Ce cas soulève de nombreuses questions uniques à la discrimination en milieu éducatif. L'auteure combine ensuite des considérations particulières au harcèlement sexuel et d'autres uniques au harcèlement en milieu éducatif. Elle note que loin de s'opposer au principe dit d'winclusivités et à la prestation d'un milieu éducatif exempt de discrimination, la liberté d'enseignement en est en fait codépendante. II s'ensuit que le droit à la liberté d'enseignement est assorti de l'obligation d'en user honnêtement et sans préjugé. En conclusion, l'auteure suggère que la liberté d'enseignement peut faire obstacle à la création d'un milieu éducatif entaché de discrimination, mais seulement quand l'expression contestée présente une valeur véritable sur le plan de l'enseignement ou de la recherche. Compte tenu de ce qui précède, la jurisprudence canadienne émergente devra trouver un juste équilibre entre les tensions inhérentes en jeu dans de telles situations.

\section{TABLE OF CONTENTS}

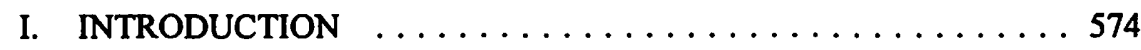

II. SEXUAL HARASSMENT $\ldots \ldots \ldots \ldots \ldots \ldots \ldots \ldots \ldots$

B.A., LL.B., LL.M.; Barrister \& Solicitor at Pundit \& Chotalia, Barristers \& Solicitors; Sessional instructor of Human Rights Law in Canada at the Faculty of Law, University of Alberta; author of The Annotated Canadian Human Rights Act 1994 (Toronto: Carswell, 1994). The author wishes to acknowledge Professor Anwar (Andy) Khan, Professor of Legal Studies at the University of Athabasca, for providing her with his file of clippings and materials and also for providing some initial input into the first draft of this article. 

A. SEXUAL HARASSMENT AS A FORM
OF SEX DISCRIMINATION . . . . . . . . . . . . 575

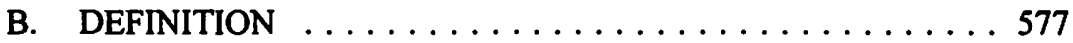
C. PARAMETERS OF SEXUAL HARASSMENT ....... 578

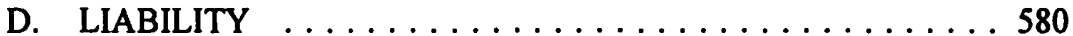

III. ROSS ON APPEAL - POISONED EDUCATIONAL

ENVIRONMENT \& FREE SPEECH $\ldots \ldots \ldots \ldots \ldots \ldots \ldots 581$

A. EDUCATION AND PUBLIC SERVICES ......... 581

B. POISONED EDUCATIONAL ENVIRONMENT

- SEXUAL HARASSMENT .............. 583

C. POISONED ENVIRONMENT HARASSMENT

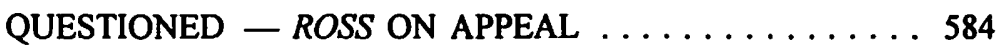

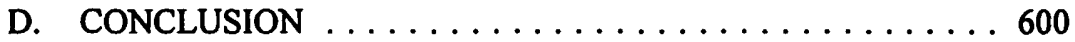

IV. EDUCATIONAL INSTITUTIONS AND

POISONED EDUCATIONAL ENVIRONMENT

SEXUAL HARASSMENT $\ldots \ldots \ldots \ldots \ldots \ldots \ldots \ldots 00 \ldots$

A. SEXUAL HARASSMENT POLICIES $\ldots \ldots \ldots \ldots \ldots 600$

B. CONFLICTS WITH ACADEMIC FREEDOM .......6602

C. EXAMPLES OF RECENT CONFLICTS

BETWEEN PROSCRIBING DISCRIMINATION

AND ACADEMIC FREEDOM $\ldots \ldots \ldots \ldots \ldots \ldots \ldots 603$

D. LEGAL ANALYSIS - POISONED

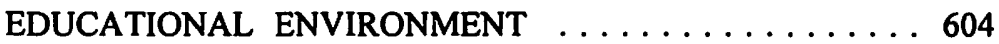

E. ACADEMIC FREEDOM - DEFINITION .........605

F. IS ACADEMIC FREEDOM A DEFENCE

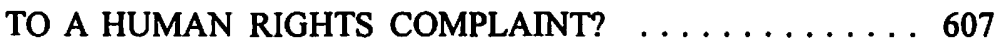

G. ANALYSIS OF A CLAIM OF

ACADEMIC FREEDOM . . . . . . . . . . . . . . 607

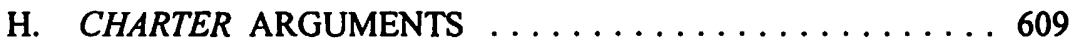

IV. CONCLUSION ....................6609

\section{INTRODUCTION}

Sexual harassment in educational institutions is not novel. Awareness has increased as greater numbers of women have been entering schools and universities. The 1992 Hill-Thomas hearings' have removed the stigma of speaking openly about sexual harassment. Frank discussion has begun to take place regarding the need for adequate legal protection from abusive conduct. A more conducive environment for the emergence of victim complaints has been created. While there has been much discourse

$1 \quad$ See D. Brock, The Real Anita Hill: The Untold Story (New York: Free Press, 1993) for a controversial discussion of the hearings. There was widespread criticism of the book; see e.g. C.A. Littleton, "Dispelling Myths About Sexual Harassment: How the Senate Failed Twice" (1992) 65 S. Cal. L. Rev. 1419; J. Mayer \& J. Abramson, "The Surreal Anita Hill" The New Yorker (24 May 1993) 40; Racing Justice, En-gendering Power: Essays on Anita Hill, Clarence Thomas, and the Construction of Social Reality (New York: Pantheon Books, 1992). 
about sexual harassment in the workplace, unique legal issues arise in the analysis of sexual harassment in an educational context.

Educational institutions have a mandate to seek and promote truth and to disseminate knowledge. Freedom of speech and academic freedom are integral to meeting this mandate. The Supreme Court of Canada affirmed that "[a]cademic freedom and excellence [are] essential to our continuance as a lively democracy." ${ }^{2}$ Freedom of thought, belief, opinion and expression are not only constitutionally guaranteed pursuant to s. 2(b) of the Charter of Rights and Freedoms, ${ }^{3}$ but such freedoms are also the universal basis of democratic rights. However, the quest for truth and knowledge cannot be successful unless it takes place within the context of a discrimination-free environment. The right to latitude in speech, research and development must correspond with a duty to be accountable to society. Given that both governmental and private sector actors are bound by federal and provincial human rights legislation which prohibits gender discrimination and sexual harassment, the question is: "how do these institutions committed to the free expression of speech demonstrate their commitment in the practical provision of a discrimination-free environment?"

This article examines the concepts of sexual harassment and the elements of poisoned environment sex discrimination and then turns to a recent controversial New Brunswick case, Attis v. New Brunswick School District No. $15^{4}$ for assistance. To what extent may a charge of sexual harassment be shielded by rights to freedom of expression and academic freedom? This article submits that freedom of expression and academic freedom are not unlimited rights, but must be exercised responsibly; they cannot excuse or justify illegal conduct, such as the creation of a poisoned educational environment.

\section{SEXUAL HARASSMENT}

\section{A. SEXUAL HARASSMENT AS A FORM OF SEX DISCRIMINATION}

In the well known decision of Janzen v. Platy Enterprises Ltd., the Supreme Court of Canada ruled that sexual harassment amounts to sex discrimination within the

2 McKinney v. University of Guelph (1990), 13 C.H.R.R. D/171 at D/201 [hereinafter McKinney].

3 Canadian Charter of Rights and Freedoms, Part I of the Constitution Act, 1982, being Schedule B to the Canada Act 1982 (U.K.), 1982, c. 11 [hereinafter the Charter]. However, s. 1 of the Charter states: "The Canadian Charter of Rights and Freedoms guarantees the rights and freedoms set out in it subject only to such reasonable limits prescribed by law as can be demonstrably justified in a free and democratic society."

4 (1992), 15 C.H.R.R. D/339 (N.B. Bd. Inq.); rev'd in part in Ross v. New Brunswick School Dist. No. 15 and Attis (1992), 16 C.H.R.R. D/250 (Q.B); further rev'd in (1993), 19 C.H.H.R. D/173 (N.B.C.A.) (date of decision December 20, 1993); leave to appeal to Supreme Court granted (1994), 116 D.L.R. (4th) vii [hereinafter Ross]. 
meaning of human rights codes. In confirming the precedent of Bell v. Ladas, ${ }^{6}$ the Court reversed the decision of Huband and Twaddle JJ.A. ${ }^{7}$ Their decision had confused sexual attraction with sexual harassment. Since Janzen, sexual harassment has universally been judicially recognized as a form of discrimination on the basis of sex or gender. Now, most Canadian human rights statutes, such as the federal statute, explicitly legislate protection against sexual harassment. ${ }^{8}$ There is well-established jurisprudence from the Supreme Court of Canada recognizing that human rights legislation has a unique quasi-constitutional nature, and that it is to be given a large, purposive and liberal interpretation. ${ }^{9}$ These laws of "fundamental importance" are not to be viewed as ordinary laws, but as being akin to constitutional laws, differing only in that they govern relations in both the private and public sector, while the Constitution applies only to government. They incorporate certain basic goals of our society. L'Heureux-Dube' J., in Canada (Attorney-General) v. Mossop, stated that:

This long line of cases mandates that courts interpret human rights legislation in a manner consistent with its overarching goals, recognizing as did my colleague Sopinka J. for the majority in Zurich

6 (1980), I C.H.R.R. D/155 (Ont. Bd. Inq.) Thereinafter Bell]. For examples of decisions following Bell, see Johnstone v. Zarankin (1985), 6 C.H.R.R. D/2651 (B.C.S.C.); Deisting v. Dollar Pizza 1978 Lid. (1982), 3 C.H.R.R. D/898 (Alta. Bd. Inq.); Phillips v. Hermiz (1984), 5 C.H.R.R. D/2450 (Sask. Bd. Inq.); Hufnagel v. Osama Enterprises Lıd. (1982), 3 C.H.R.R. D/922 (Man. Bd. Adj.); Foisy v. Bell Canada (1984), 6 C.H.R.R. D/2817 (Que. Sup. Ct.); Doherty v. Lodger's International Ltd. (1981), 3 C.H.R.R. D/628 (N.B. Bd. Inq.); Mehta v. Mackinnon (1985), 67 N.S.R. (2d) 429 (C.A.); Commodore Business Machines Ltd. v. Olarte (1984), 6 C.H.R.R. D/2833 (Ont. S.C.); as compiled and commented upon in A. Aggarwal, Sexual Harassment in the Workplace, 2d ed. (Toronto: Butterworths, 1992).

7 Janzen v. Platy Enterprises Ltd. (1987), 8 C.H.R.R. D/3831 (Man. C.A.). Twaddle J.A. concluded that sexual harassment based on the "sex appeal" of the victim could not constitute sex discrimination (at D/3846-47), while Huband J.A. stated:

I am amazed to think that sexual harassment has been equated with discrimination on the basis of sex ... I am amazed to think that an employer could be held vicariously responsible for that form of discrimination on the part of an employee, or that a corporate employer could be found "personally responsible" for a sexually malevolent employee, except under the rarest of circumstances. (ibid. at D/3832).

This decision has been widely criticized. See e.g. M. Burka, "Sexual Harassment: Manitoba's Step Backward: A Case Comment on Govereau and Janzen v. Platy Enterprises Ltd." (1987) 16:3 Man. L.J. 245; M.A. Hickling "Employer's Liability For Sexual Harassment" (1988) 17:2 Man. L.J. 124; I.F. Ivankovich, "Sexual Harassment in the Workplace - Two Steps Backward: Janzen \& Govereau v. Platy Enterprises Ltd." (1988) 26 Alta. L. Rev 359; "Serious Setback for Women Across the Country: Justices Wipe Out Sex Harassment Protections" (1987) 3:1 Can. H.R. Advoc. 1.

Canadian Human Rights Act, R.S.C. 1985, c. H-6. [hereinafter C.H.R.A.].

See Insurance Corp. of B.C. v. Heerspink, [1982] 2 S.C.R. 145; Ontario (Human Rights Commission) v. Simpsons Sears Ltd., [1985] 2 S.C.R. 536; Canadian National Railway Co. v. Canada (Canadian Human Rights Commission), [1987] 1 S.C.R. 1114 (sub nom. Action Travail des Femmes v. C.N.R. Co.) [hereinafter Action Travail des Femmes]; Robichaud v. Canada (Treasury Board), [1987] 2 S.C.R. 84, 87 C.L.L.C. 17,025 [hereinafter Robichaud]; Zurich Insurance Co. v. Ontario (Human Rights Commission), [1992] 2 S.C.R. 321. For a general review, see A.L.W. D'Silva, "Giving Effect to Human Rights Legislation - A Purposive Approach" (1991) 3 Windsor Rev. L. \& S. Issues 45. 
Insurance, ... that such legislation is often "the final refuge of the disadvantaged and the disenfranchised." 10

Although the rights are not entrenched, the legislation, in effect, creates a "constitution" for the private sector. Thus, freedom from sexual harassment, as from other forms of discrimination, is a fundamental aspect of Canadian society.

\section{B. DEFINITION}

Janzen also examined the parameters of sexual harassment. It prescribed a very broad definition of sexual harassment, as an abuse of power constituted by any unwelcome behaviour of a sexual nature. The Supreme Court of Canada quoted the American case of Meritor Savings Bank v. Vinson" with approval, in holding that sexual harassment is any:

[U]nwelcome conduct of a sexual nature that detrimentally affects the work environment or leads to adverse job-related consequences for the victims of harassment. It is ... an abuse of power. When sexual harassment occurs in the workplace, it is an abuse of both economic and sexual power. Sexual harassment is a demeaning practice, one that constitutes a profound affront to the dignity of the employees forced to endure it. By requiring an employee to contend with unwelcome sexual actions or explicit sexual demands, sexual harassment in the workplace attacks the dignity and self-respect of the victim both as an employee and as a human being. ${ }^{12}$

The Supreme Court of Canada also affirmed the decision in Bell, that prohibited conduct includes a broad spectrum of conduct ranging from

overt gender based activity, such as coerced intercourse to unsolicited physical contact to persistent propositions to more subtle conduct such as gender based insults and taunting, which may reasonably be perceived to create a negative psychological and emotional work environment. ${ }^{13}$

Although the Supreme Court of Canada rejected the U.S. Supreme Court's approach of categorizing sexual harassment as either tangible benefit/quid pro quo harassment or hostile/offensive working environment harassment, ${ }^{14}$ these two categories are of assistance in identifying the range of prohibited offensive behaviour. Quid pro quo harassment involves the granting or withholding of an economic benefit in exchange for a sexual demand; e.g., demands for sexual favours made under threats of adverse

191 L. Ed. (2d) 55 (1986). The United States Supreme Court held, in a unanimous decision on this point, that without question sexual harassment was a form of sex discrimination and that hostile environment and quid pro quo harassment both violated Title VIl of the Civil Rights Act. Therefore, one need not show tangible economic loss in order to bring an action. For a comparative analysis of American and Canadian sexual harassment laws, see S. Chotalia, "Sexual Harassment Laws in Canada - It's all a Question of Power" (1994-95) 3:2 J. Indiv. Emp. R. 155. Janzen, supra note 5 at 1284 .

$13 \quad$ Supra note 6 at 156.

$14 \quad$ Janzen, supra note 5 at 1283. 
job consequences. In Janzen, the Court confirmed that while this was one form of harassment, albeit a particularly blatant and ugly form, sexual harassment

also encompasses situations in which sexual demands are foisted upon unwilling employees or in which employees must endure sexual groping, propositions and inappropriate comments, but where no tangible economic rewards are attached to involvement in the behaviour. ${ }^{\text {is }}$

The concept of "negative psychological and emotional work environment" propounded in Bell had been expanded in Dhillon v. F.W. Woolworth Co. Ltd., ${ }^{16}$ wherein Board Chairman Professor Cumming drew an analogy between racial and sexual harassment with respect to the work environment and concluded:

[t]he atmosphere of the workplace is a "term or condition of employment" just as much as more visible terms or conditions, such as hours of work or rate of pay. The words "term or condition of employment" are broad enough to include the emotional and psychological circumstances in the workplace. There is a duty on every employer to take reasonable steps to eradicate this form of discrimination. ${ }^{17}$

In reaching his conclusion, Professor Cumming examined in detail the authoritative American case of Bundy v. Jackson, ${ }^{18}$ which held that a poisoned work environment requires neither proof of tangible actions against an employee, nor proof of resistance to the harassing conduct. The Court in Bundy examined cases wherein employees had been subjected to ethnic or racial slurs. Janzen accepted these parameters in confirming that sexual harassment is any sexually-oriented practice that endangers an individual's continued employment, negatively affects his or work performance, or undermines his or her sense of personal dignity. Dickson C.J. for the Court wrote:

[S]exual harassment in the workplace may be broadly defined as unwelcome conduct of a sexual nature that detrimentally affects the work environment or leads to adverse job-related consequences for the victims of the harassment. ${ }^{19}$

\section{PARAMETERS OF SEXUAL HARASSMENT}

Janzen held that the focus of the inquiry is centred around whether or not the particular conduct was "welcomed" by the complainant from the alleged harasser:

Ibid. at 1282.

(1982), 3 C.H.R.R. D/743 (Ont. Bd. Inq.).

lbid. at $\mathrm{D} / 763$.

18641 F. 2d 934 (D.C. Cir. 1981) [hereinafter Bundy]. Recently, the U.S. Supreme Court in Harris v. Forklift Systems, Inc., 114 S. Ct. 367 (1993) unanimously decided that an employer can be forced to pay monetary damages even when the employee who suffers sexual harassment suffers no psychological harm. Justice Sandra Day O'Connor wrote on behalf of the Court: "[s]o long as the environment would reasonably be perceived, and is perceived, as hostile or abusive ... there is no need for it also to be psychologically injurious" (ibid. at 371). For analysis of the case see B.B. Brown \& I.L. Germanis, "Hostile Environment Sexual Harassment: Has Harris Really Changed Things?" (1994) 19 Empl. Rel. L.J. 567; R.K. Robinson, R.L. Fink \& B.M. Allen, "Unresolved Issues in Hostile Environment Claims of Sexual Harassment" (1994) 45:2 L.L.J. 110. Janzen, supra note 5 at 1284. 
The main point in allegations of sexual harassment is that unwelcome sexual conduct has invaded the workplace, irrespective of whether the consequences of the harassment included a denial of concrete employment rewards for refusing to participate in sexual activity. ${ }^{20}$

The complainant's "voluntariness" is not the issue. ${ }^{21}$ The analysis is fact dependent, although general legal guidelines regarding determination of "welcomeness" have been developed. For example, in Kotyk v. Canada (Canadian Employment and Immigration Commission) ${ }^{22}$ the Tribunal ruled that the avoidance of physical closeness, persistent social invitation or sexual conduct of a superior is tantamount to notice that the behaviour is not welcomed by the complainant. The Bell case cautions that normal social intercourse between employer and employee is not prohibited conduct. This caution was reiterated in Aragona v. Elegant Lamp Co.:

[S]exual references which are crude or in bad taste, are not necessarily sufficient to constitute a contravention of section 4 of the [Ontario] Code on the basis of sex. The line of sexual harassment is crossed only where the conduct may be reasonably construed to create, as a condition of employment, a work environment which demands an unwarranted intrusion upon the employee's sexual dignity as a man or woman. The line will seldom be easy to draw.... ${ }^{23}$

Given that such conduct is to be judged by the objective standard of the "reasonable person," 24 the task of characterizing behaviour as constituting a poisoned work environment is particularly difficult. It is submitted that the more appropriate standard should be the one presently evolving in the United States, namely the "reasonable woman" standard. ${ }^{25}$ Would a "reasonable woman" consider the conduct offensive and demeaning to her dignity? In the American case of Robinson v. Jacksonville Shipyards, ${ }^{26}$ the District Court acknowledged that there are significant differences between the perceptions of men and women as to what constitutes sexual harassment. In that case, the female complainant alleged harassment due to: the number of calenders portraying females (nude or semi-nude) in provocative positions; lewd, suggestive and offensive behaviour and language from co-workers and supervisors; and the failure of

Ibid. at 1283 [emphasis added].

See Re Canada Post Corp. and Canadian Union of Postal Workers (1987), 27 L.A.C. (3d) 27 (C.L.R.B.).

(1983), 4 C.H.R.R. D/1416 (C.H.R.T.) [hereinafter Kotyk].

(1982), 3 C.H.R.R. D/1 109 at D/1110 (Ont. Bd. Inq.) [hereinafter Aragona].

See Kotyk, supra note 22; Bell, supra note 6; ibid. note 23; Pachouris v. St. Vito llalian Food (1984), 5 C.H.R.R. D/1944 (Ont. Bd. Inq.) discussing permissive vulgar comments.

See Ellison v. Brady, 924 F.2d 872 (9th Cir. 1991); Robinson v. Jacksonville Shipyards Inc., 760 F. Supp. 1486 (M.D. Fla. 1991); Kauffman v. Allied Signal Inc., 970 F.2d 178 (6th Cir. 1992) cert. denied, 113 S. Ct. 831 (1993) (6th Cir.); Yates v. Avco Corp., 819 F.2d 630 (6th Cir. 1987); Carrillo v. Ward, 770 F. Supp. 815 at 822 (S.D.N.Y. 1991); Vermette v. Hough, 627 F. Supp. 587 at 605 (W.D. Mich. 1986) which use the "reasonable woman" test. Contra for the objective test see Rabidue v. Osceola Refining Co., 805 F.2d 611 (6th Cir. 1986); Andrews v. City of Philadelphia, 895 F.2d 1469 (3rd Cir. 1990). For a combined objective and subjective test see Dockter v. Rudolf Wolff Futures, Inc., 913 F.2d 456 at 459 (7th Cir. 1990); King v. Board of Regents, 898 F. 2d 533 at 537 (7th Cir. 1990); Brooms v. Regal Tube Co., 881 F.2d 412 at $418-19$ (7th Cir. 1989). 
management to respond to her complaint. ${ }^{27}$ Expert evidence was led that such materials and conduct "sexualize" the workplace and reinforce the view that women are sexual objects, and that women are more significantly affected by the "sexualization" of the workplace than men. Expert evidence was also led that coping mechanisms include denial of the behaviour, absenteeism, apparent acceptance of the behaviour, and further that sexual harassment affects women more adversely than men. ${ }^{28}$ Legal acknowledgement that women must be free of sexual harassment requires acceptance of the differences between male and female tolerance to a poisoned work or educational environment. It is submitted that Canadian courts should and will move towards the evolving "reasonable woman" standard of proof.

\section{LIABILITY}

Having noted American advances in the area of onus of proof and evidence, it is important to acknowledge that the Supreme Court of Canada has confirmed broad employer liability for employee sexual harassment in Robichaud. ${ }^{29}$ Thereafter in Janzen, Dickson C.J. adopted the Robichaud reasoning. ${ }^{30}$ In Robichaud, the Court considered the liability of an employer for sexual harassment under the C.H.R.A., where the harassment was committed by a foreman. The relevant C.H.R.A. section stated:

7. It is a discriminatory practice, directly or indirectly,

(a) to refuse to employ or continue to employ any individual, or

(b) in the course of employment, to differentiate adversely in relation to an employee on a prohibited ground of discrimination. ${ }^{31}$

La Forest $\mathrm{J}$. began by analyzing the statute itself in regards to its purpose and nature. ${ }^{32}$ The Supreme Court had already held that the C.H.R.A. was to be interpreted in a generous and liberal fashion befitting the "special nature" of the legislation, so as to advance the broad policy considerations underlying it. The legislation was described as fundamental and quasi-constitutional. ${ }^{33} \mathrm{La}$ Forest $\mathrm{J}$. found that the purpose of the C.H.R.A. was "to give effect to the principle of equal opportunity for individuals by eradicating invidious discrimination," and that the statute was "not primarily aimed at punishing those who discriminate." ${ }^{34}$ The C.H.R.A. was "essentially concerned with the removal of discrimination, as opposed to punishing anti-social behaviour, [and

Ibid. at 1494-98.

Ibid. at 1502-07. See also D. Niven, "The Case of the Hidden Harassment" (1992) 70:2 Harv. Bus. Rev. 12 at 23.

Supra note 9.

Supra note 5 at $1292 \mathrm{ff}$.

Supra note 8 at 5.7 [emphasis added].

Robichaud, supra note 9 at 89 . La Forest J. said:

The purpose of the Act is set forth in s. 2 as being to extend the laws of Canada to give effect to the principle that every individual should have an equal opportunity with other individuals to live his or her own life without being hindered by discriminatory practices based on certain prohibited grounds of discrimination, including discrimination on the ground of sex.

See generally, supra note 9 and discussion in Part IIA below.

Robichaud, supra note 9 at 90 . 
therefore] the motives or intention of those who discriminate are not central to its concerns. ${ }^{.35}$ As in Charter jurisprudence, it is the effect of the acts that is in question.

In dealing with the question of whether the sexual harassment could be attributed to the employer, La Forest J. held that theories of employer liability developed in the context of criminal law or quasi-criminal law were inappropriate: "These are completely beside the point as being fault oriented, for, as we saw, the central purpose of a human rights Act is remedial - to eradicate anti-social conditions without regard to the motives or intention of those who cause them. ${ }^{136} \mathrm{He}$ also disposed of the argument that a tort-based vicarious liability approach is relevant by the same observation, because it "cannot meaningfully be applied to, the present statutory scheme. ${ }^{1.37}$ The Court found that the legislative emphasis on prevention and elimination of undesirable conditions, rather than on fault, moral responsibility and punishment, argued for making the C.H.R.A.'s carefully crafted remedies effective. ${ }^{38}$ La Forest $\mathrm{J}$. then stated:

Indeed, if the Act is concerned with the effects of discrimination rather than its causes (or motivations), it must be admitted that only an employer can remedy undesirable effects; only an employer can provide the most important remedy - a healthy work environment. ${ }^{39}$

Using this purposive approach, the Supreme Court of Canada concluded that the statute requires that employers be held liable for the discriminatory acts of all of their employees where those actions are "in some way related or associated with the employment. ${ }^{140}$ The Court held that the conduct of an employer is theoretically irrelevant to the imposition of liability, but may affect possible remedies. ${ }^{41}$

\section{ROSS ON APPEAL - POISONED EDUCATIONAL ENVIRONMENT \& FREE SPEECH}

All the cited cases of sexual harassment arose out of incidents in the workplace. Are the concepts of a "poisoned work environment" transferable to a "poisoned educational environment"? It is submitted that they are.

\section{A. EDUCATION AND PUBLIC SERVICES}

Human rights legislation prohibits discrimination in both employment and in the provision of public services. For example, in the C.H.RA., s. 5, dealing with "Denial of good, service, facility or accommodation," states:

It is a discriminatory practice in the provision of goods, services, facilities or accommodation customarily available to the general public

$\begin{array}{ll}35 & \text { Ibid. } \\ 36 & \text { Ibid. at } 91 . \\ 37 & \text { Ibid. } \\ 38 & \text { Ibid. at } 92 . \\ 39 & \text { Ibid. at } 94 . \\ 40 & \text { Ibid. at } 95 . \\ 41 & \text { Ibid. at } 96 .\end{array}$


(a) to deny, or to deny access to, any such good, service, facility or accommodation to any individual, or

(b) to differentiate adversely in relation to any individual,

on a prohibited ground of discrimination.

The wording of the section closely parallels that in s. 7 of the Act (as quoted above), which deals with employment. While s. 5 does not expressly refer to "direct" or "indirect" differentiation, as does s. 7 , it is submitted that these words are not conclusive. The "poisoned work environment" analysis in Janzen arose out of an examination of s. 6(1)(a) of the Manitoba Human Rights Act which did not include these words. ${ }^{42}$ Further, the courts place emphasis on larger human rights principles as determinative, rather than on specific statutory differences. Referring to Linden J.A.'s decision in Canada (A.G.) v. Rosin, ${ }^{43}$ Lamer C.J. in Berg v. University of British Columbia wrote, "it appears that the specific wording of the particular sections at issue was rarely the determinative element in previous decisions. ${ }^{144}$

\section{Lamer C.J. also stated that:}

[i]f human rights legislation is to be interpreted in a purposive manner, differences in wording between provinces should not obscure the essentially similar purposes of such provisions, unless the wording clearly evinces a different purpose on behalf of a particular legislature. ${ }^{15}$

In Berg, the Supreme Court further held that the provision of university education constituted the provision of "public services" within the context of human rights legislation. Indeed, Lamer C.J., writing for the majority, confirmed that universities may not discriminate with respect to students seeking admission, nor with respect to enrolled students. ${ }^{46}$ In considering the application of s. 3 of the British Columbia Human Rights $A c t,{ }^{47}$ being the public services provision, the Court used its established interpretation method to give s. 3 a broad, liberal and purposive meaning. After

S.M. 1974, c. 65, s. 6(1)(a) as amended, read, "no employer or person acting on behalf of an employer shall refuse to employ, or to continue to employ or to train the person for employment or to advance or promote that person, or discriminate against that person in respect of employment or any term or condition of employment." [1991] 1 F.C. 391 (F.C.A.) [hereinafter Rosin].

44 [1993] 2 S.C.R. 353 at 373 [hereinafter Berg]. Lamer C.J. also confirmed the position of Wilson J.A. (as she then was), dissenting, in Re Ontario Human Rights Commission and Ontario Rural Sofiball Association (1980), 26 O.R. (2d) 134 at 141 (C.A.), where she stated that, despite differences in wording between two provincial statutes, judicial principles would apply equally to cases under the different statutes.

is Berg, ibid.

4 Ibid. at 383

$47 \quad$ S.B.C. 1984 , c. 22 , s. 3 read:

No person shall (a) deny to a person or class of persons any accommodation, service or facility customarily available to the public, or (b) discriminate against any person or class of persons with respect to any accommodation, service or facility customarily available to the public, because of ... [the prohibited grounds]. 
reviewing analogous provisions in other human rights statutes, the Court accepted Linden J.A.'s simple articulation in Rosin, that "[t]he essential aim of the wording is to forbid discrimination by enterprises which purport to serve the public." ${ }^{188}$ Lamer C.J. rejected a purely quantitative analysis, and any definition of "public" which refused to:

[R]ecognize that any accommodation, service or facility will only ever be available to a subset of the public.... Instead, in determining which activities of the School are covered by the Act, one must take a principled approach which looks to the relationship created between the service or facility provider and the service or facility user by the particular service or facility. Some services or facilities will create public relationships between the School's representatives and its students, while other services or facilities may establish only private relationships between the same individuals.9

In its analysis the Court accepted the reasoning of New Brunswick School District No. 15 v. New Brunswick (Human Rights Board of Inquiry) ${ }^{\text {so }}$ which held that public education provided under the New Brunswick School Act is a service available to the public. Therefore, one can conclude that public education provided by universities and schools is subject to human rights legislation.

\section{B. POISONED EDUCATIONAL ENVIRONMENT — SEXUAL HARASSMENT}

Thus, like employers, universities and schools offering services to the public are obligated to provide these services in discrimination-free environments. It is logical and appropriate to transpose the concepts of workplace sexual harassment to educational sexual harassment. In Janzen, Dickson C.J. extensively examined definitions of sexual harassment, including that of Professor Catherine MacKinnon, who broadly defined sexual harassment as "the unwanted imposition of sexual requirements in the context of a relationship of unequal power." ${ }^{51}$ Dickson C.J. also quoted Arjun P. Aggarwal, who wrote:

Sexual harassment is a complex issue involving men and women, their perceptions and behaviour, and the social norms of the society.... It occurs not only in the workplace and in the classroom, but even in parliamentary chambers and churches. Sexual harassment may be an expression of power or desire or both. Whether it is from supervisors, co-workers, or customers, sexual harassment is an attempt to assert power over another person. ${ }^{52}$

Dickson C.J. accepted the common denominator of these and other definitions as being the concept of "using a position of power to import sexual requirements into the workplace thereby negatively altering the working conditions of employees who are forced to contend with sexual demands." ${ }^{\text {"33 }}$ It is submitted that the Janzen definitions

Berg, supra note 44 at 373 , citing Rosin, supra note 43 at 398.

Berg, ibid. at 383-84.

lbid. at 376, citing (1989), 10 C.H.R.R. D/6426 (N.B.C.A.).

Janzen, supra note 5 at 1280, quoting from C.A. MacKinnon, Sexual Harassment of Working Women: A Case of Sex Discrimination (New Haven: Yale University Press, 1979) at 1.

Janzen, ibid., quoting A.P. Aggarwal, Sexual Harassment in the Workplace (Toronto: Butterworths, 1987) at 1 [emphasis added].

Janzen, ibid. at 1281 . 
are equally appropriate to the educational environment because of the broad parameters of sexual harassment. Recently, in $A$. v. E. ${ }^{54}$ Martin Zucker, Hearing Chair, applied cases of workplace sexual harassment to the university educational environment, holding that students are bound by the law of sexual harassment. It is submitted that the broad purposive approach in interpreting human rights legislation outlined in Robichaud contemplates that terms and conditions of both work and study in educational institutions include a discrimination-free environment; i.e. that unwelcome sexual conduct should not be allowed to detrimentally affect either the workplace, or the place of study. Transposing the Aragona definition into the educational context is appropriate: when conduct may be reasonably construed as creating a condition of education, or an educational environment, that demands an unwarranted intrusion upon the student's sexual dignity, as a man or a woman, sexual harassment is established. ${ }^{55}$

\section{POISONED ENVIRONMENT HARASSMENT QUESTIONED - ROSS ON APPEAL}

\section{Facts and Issues}

A controversial decision on educational discrimination will soon be heard by the Supreme Court of Canada. The Supreme Court has granted leave to appeal in Ross. ${ }^{56}$ The complainant in the case, David Attis, a Jewish resident of Moncton, filed a human rights complaint against Malcolm Ross and the Board of Trustees of District 15, alleging that the racist and bigoted statements of Mr. Ross led to a poisoned educational environment for his children and that the School Board, by condoning Mr. Ross' views, was also liable for discrimination. Mr. Ross started teaching in District 15 in 1971. Between that date and the hearing date, Mr. Ross published several books alleging that the Holocaust was a hoax and warning readers about a Jewish conspiracy. Mr. Ross made numerous media and public appearances to promote his views which led to his views becoming well-known in the local community, both in and beyond his school district. However, there was no recent evidence that Mr. Ross had promoted his views in the classroom. The Board of Inquiry was charged with having to determine whether these attacks on Jewish people and the Jewish faith by a school teacher led to discrimination in the provision of services by the School Board and Mr. Ross.

2. Decision of the Board of Inquiry

a. Poisoned Environment Discrimination

The Board of Inquiry constituted pursuant to the province's human rights statute held that children have the right to an educational environment free of discrimination, and 
held that in this case Attis had made out a prima facie case of discrimination. ${ }^{57}$ In analyzing the services provided in an educational facility and the education of students, the Board correctly noted that:

Education of students must be viewed in the broad context of including not only the formal curriculum but the more informal aspects of education that come through interchange and participation in the whole school environment. This would be in keeping with the broad purposive approach taken to the interpretation of human rights legislation.... Section 5 attempts to create a learning environment which is as free from discriminatory effects as is reasonably possible given the influence of factors beyond the control of those administering the educational system. In the present case it is claimed that the complainant and his children, on the basis of their religion or ancestry, are provided with an inferior or less secure learning environment than is available to parents and children of other religions and ancestries. This less secure environment, the complainant argues, has created apprehensions, fears, anger, isolation, and in a broader context has attacked the dignity and self-worth of the complainant and his children. It has been claimed that the School Board and Malcolm Ross have created a "poisoned environment" in School District 15 for the complainant and his children."

In accepting these arguments, the Board of Inquiry quoted the Respondent School Board's position as put forward in a 1989 television interview, when the School Board ordered Ross to refrain from publicly assailing and denouncing another religion. The School Board stated that:

[T] he climate created by this aggressive approach creates hostility that permeates and interferes with the desired tolerance required by the school system to show respect for the rights of all students and their families to practice their religious faith..$^{59}$

The Board then held:

This Board of Inquiry has no hesitation in concluding that the public statements and writings of Malcolm Ross have continually over many years contributed to the creation of a poisoned environment within School District 15 which has greatly interfered with the educational services provided to the complainant and his children. ${ }^{60}$

The Board of Inquiry held that the Board of School Trustees was liable for the poisoned environment created by its mathematics teacher, Ross, who published antisemitic and racist books and made such statements outside of the classroom. It held that the Board of Trustees was liable as an employer for the breaches of its teachers. ${ }^{61}$

Ibid. at D/353-60 (N.B. Bd. Inq.). The onus of proving discrimination is upon the complainant on a balance of probabilities: see Ontario (Human Rights Commission) v. Etobicoke, [1982] 1 S.C.R. 202 at 208, 3 C.H.R.R. D/781 [hereinafter Erobicoke].

Ross, ibid. at $\mathrm{D} / 353-54$.

Jbid. at $\mathrm{D} / 357$.

Ibid.

Ibid. In the context of employment, employers have an obligation to create and maintain a discrimination-free environment. The employer has a duty to end discrimination in the workplace; failure to take action against racial harassment creates the impression that management condones such practices. See Pitawanakwat v. Canada (Secretary of State) (1993), 93 C.L.L.C. 16,074 
However, it also held that the Board of Trustees failed to discipline the teacher for his conduct and its negative effects on the students, and thereby discriminated against the complainant directly. The Board of Inquiry then ordered the Department of Education to implement specific measures to create a discrimination-free educational environment. ${ }^{62}$ It also ordered:

2. that the School Board:

(a) immediately place Malcolm Ross on a leave of absence without pay for a period of eighteen months;

(b) appoint Malcolm Ross to a non-teaching position if, within the period of time that Malcolm Ross is on leave of absence without pay, a non-teaching position becomes available in School District 15 for which Malcolm Ross is qualified. The position shall be offered to him on terms and at a salary consistent with the position. At such time as Malcolm Ross accepts employment in a non-teaching position his leave of absence without pay shall end.

(c) terminate Malcolm Ross' employment at the end of the eighteen-month leave of absence without pay if, in the interim, he has not been offered and accepted a non-teaching position.

(d) terminate Malcolm Ross' employment with the School Board immediately if, at any time during the eighteen-month leave of absence period or if at any time during his employment in a non-teaching position, he:

(i) publishes or writes for the purpose of publication, anything that mentions a Jewish or Zionist conspiracy, or attacks followers of the Jewish religion, or

(ii)publishes, sells, or distributes any of the following publications, directly or indirectly:

- Web of Deceit

- The Real Holocaust (The Attack on Unborn Children and Life Itself)

- Spectre of Power

- Christianity vs. Judeo-Christianity (The Battle for Truth) ${ }^{63}$

\section{b. Poisoned Educational Environment and Teaching Duties}

Provisions 2(a), 2(b) and 2(c) of the order are an attempt to curtail poisoned educational environment discrimination by preventing Mr. Ross from teaching. The Board wrote:

(C.H.R.T.), rev'd in part in [1994] 3 F.C. 298 (F.C.T.D.), 94 C.L.L.C. 17,013, Gibson J. The Tribunal found that "racial slurs, jokes and stereotyping did occur in the work place during the [Principal Applicant's] tenure" (at 16,080). See also Gannon v. Canadian Pacific Ltd. (1993), 93 C.L.L.C. 16,148 (C.H.R.T.), wherein the employer was held liable for racial harassment of a black employee; and Hinds v. Canada (Employment \& Immigration Commission) (1988), 24 C.C.E.L. 65 (C.H.R.T.) wherein a charge of racial harassment, perpetrated by an unknown employee of the Respondent, was upheld. Compiled in S. Chotalia, The Annotated Canadian Human Rights Act 1994 (Toronto: Carswell, 1994).

Ross, $i b i d$. at $\mathrm{D} / 361$. The measures ordered were: to establish an annual review process; to set goals and to assess progress in multi-cultural and human rights education; to develop a system of appraisals of the quality of race relations in schools; to encourage all boards and teachers to implement human rights policies; to review the School Act in terms of misconduct provisions. 
Malcolm Ross, by his writings and his continued attacks, has impaired his ability as a teacher and cannot be allowed to remain in that position if a discrimination-free environment is to exist.... The only viable solution is that Malcolm Ross must be removed from the classroom. ${ }^{64}$

Thus, the Board viewed Mr. Ross' teaching position as being the link between his discriminatory extra-curricular activities and the creation of a poisoned educational environment at the school where he taught. In assessing the evidence, the Board had examined the case law surrounding off-duty conduct of teachers and had focused on:

[T] he fact that teachers are role models for students whether a student is in a particular teacher's class or not. In addition to merely conveying curriculum information to children in the classroom, teachers play a much broader role in influencing children through their off-duty lifestyle. ${ }^{\text {os }}$

Unfortunately, the Board of Inquiry did not examine similar considerations for a "non-teaching position," although it did specify in the judgment that its intent was to allow Mr. Ross to work in a non-teaching position, in which student contact was minimal, if any, and that the complainant did not object to such an order. ${ }^{66}$ With respect, it is submitted that the consent of the complainant is not a relevant factor in the making of a remedial human rights order. Such legislation aims not only at correcting discriminatory practices for the complainant, but also at rectifying future discriminatory practices for others. It is submitted that an analysis as outlined by McLachlin J.A., as she then was, in Cowichan School District 65 v. Peterson ${ }^{67}$ would have been appropriately transposed into the determination of the content of the remedial order:

The question is what is required to protect the school community from harm. In answering this question, it must be borne in mind that harm can take different forms. The risk that the misconduct may recur with resultant injury to students is one type of harm. The danger of students being influenced by inappropriate role models is another type of harm. Loss of respect with a consequent diminution [sic] of teaching effectiveness may cause harm to the school community. Yet another type of harm which may be perpetrated by retention of a teacher found guilty of misconduct is a public loss of confidence in the educational system. ${ }^{68}$

The issue is not one of simply punishing Ross, but of considering what is necessary to ensure the proper and safe provision of education. The risk of other students and staff discriminating against Jewish children, the danger that students and staff may imitate Ross' discriminatory conduct, the loss of respect for the guilty respondent resulting in decreased effectiveness in job performance, and the public loss of confidence in the

(1988), 22 B.C.L.R. (2d) 98 (C.A.) [hereinafter Cowichan]. Mr. Peterson was suspended and then dismissed by the Cowichan School Board under the provincial School Act. The suspension and the dismissal were for misconduct. The conduct in question consisted of two incidents of sexual intimacy between Mr. Peterson and a young woman of about eighteen years of age (ibid. at 99 , 
educational system are some of the factors to be considered in the making of a remedial order in the case of poisoned educational environment discrimination. Further, it is submitted that a poisoned educational environment could also result from Mr. Ross' holding of a number of non-teaching positions. For example, Mr. Ross could have obtained the non-teaching position of school counsellor, or even school principal. Would this break the nexus between his off-duty activities and the creation of a poisoned educational atmosphere at the school? One would suspect not. These positions involve role-modelling obligations, are positions of trust and authority, and although not involving direct classroom education, would most likely equally lead to public loss of confidence in the educational system.

If parents cannot send their children to school in the confidence that they will be guided by morally responsible and trustworthy teachers, they cannot be expected to support the system and encourage their children to take maximum advantage of it. ${ }^{69}$

These sentiments are equally applicable to principals, counsellors and other educators in positions of trust and authority.

Rather than focusing on a specific category analysis (e.g., off-duty vs. on-duty conduct; in classroom vs. out of classroom activity), it is submitted that a relational and factual analysis in the circumstances of each case is appropriate to determine whether or not a finding of a poisoned educational environment is justified, and to determine the appropriate remedy. What is the nexus between the discriminatory conduct and the position of the offender? Is the offender's employment status a factor in the creation of the poisoned educational environment? The analysis should have been conducted vis-à-vis careful analysis of the complaint:

By its own statements and its inaction over Malcolm Ross' statements in class and in public, the School Board has condoned his views, has thus provided a racist and anti-Jewish role model for its students, has fostered a climate where students feel more at ease expressing anti-Jewish views, and has reduced the credibility of the content of its official history curriculum, thus depriving Jewish and other minority students of equal opportunity within the educational system that the School Board provides as a service to the public. ${ }^{70}$

How did Ross' off-duty conduct foster a racist climate for Jewish students and how did his teaching position reduce the credibility of the content curriculum? Is a teacher not in a position of trust and authority in the school?

It is submitted that on the facts of this case, the Board could have simply ordered the termination of Mr. Ross. 
The matter may be viewed in another way. Some breaches of the employment relationship are so serious that they may be regarded as fundamental, entitling the employer to accept them as a repudiation of the contract of employment and terminate it."

In Ross did not the flagrant and persistent discriminatory conduct, being a violation of "quasi-constitutional" law, constitute a repudiation of the employment contract and a fundamental breach? Was it not cause for dismissal? Was it not morally repugnant? Would the Board not have, by retaining Mr. Ross in any capacity, been seen by the "reasonable person"/"reasonable child"/"reasonable minority member" as having condoned his racist views? Did Ross' conduct not constitute an unwarranted intrusion upon the students' racial dignity? ${ }^{72}$ Did the facts not show that there were reasonable grounds to believe that Mr. Ross would have continued to engage in the discriminatory and racist behaviour? The implied terms of a contract of employment are that the parties must comply with human rights laws. Parties cannot contract out of human rights laws which constitute public policy. ${ }^{73}$ As has been stated by the Supreme Court of Canada:

\footnotetext{
Human rights legislation is intended to give rise, amongst other things, to individual rights of vital importance, rights capable of enforcement, in the final analysis, in a court of law. I recognize that in the construction of such legislation the words of the $A c t$ must be given their plain meaning, but it is equally important that the rights enunciated be given their full recognition and effect. We should not search for ways and means to minimize those rights and to enfeeble their proper impact. ${ }^{74}$
}

It is submitted that, on the facts before the Board of Inquiry, the termination of Ross could and would have been an appropriate order. The Board's order to allow Mr. Ross to continue in a non-teaching position was not a satisfactory solution to its finding of discrimination.

\section{c. Poisoned Educational Environment and Non-Teaching Duties}

In apparent contradiction to the above portions of the order, the Board of Inquiry then provided for the termination of Mr. Ross while employed in a non-teaching capacity. The Board of Inquiry wrote:

Should Malcolm Ross be placed in such a non-teaching position, his continued employment would, of course, be dependent upon him not publishing, writing or selling, directly or indirectly, any publication that mentions a Jewish or Zionist conspiracy.... ${ }^{75}$

Here, it appears as though the Board linked the past and future creation of a poisoned educational environment with Mr. Ross' employment with the School Board in any 
capacity. Unfortunately, the Board's factual analysis is betrayed by this contradiction in its order.

\section{Queen's Bench Decision}

\section{a. Order Against a Non-Offender}

On appeal, Creaghan J. of the Court of Queen's Bench quashed those parts of the order directed towards the Board of Education on the basis that the Board of Inquiry exceeded its jurisdiction. Section 20(6.2) of the New Brunswick Human Rights Act ${ }^{76}$ outlined the power of the Board of Inquiry and provided that the Board may order any party "found to have violated the $A c t$ " to "do or refrain from doing, any act or acts so as to effect compliance with the Act"; or "to rectify any harm caused by the violation...." It is submitted that Ceaghan J. correctly analyzed this portion of the Board of Inquiry's order:

In this instance, there was no claim that the Department of Education violated the Act; there was no investigation as to whether the Department of Education violated the $\mathrm{Act}$; and there was no finding that the Department of Education violated the Act. There was no jurisdiction in the Board of Inquiry to make an order requiring compliance by the Department of Education simply because it was designated as a party to the inquiry. ${ }^{77}$

\section{b. Standard of Review}

The Court of Queen's Bench refused to overturn the Board of Inquiry's order to remove Ross from a teaching position. ${ }^{78}$ The Court held that the Board acted within its jurisdiction, and that s. 21(1) of the New Brunswick Human Rights $A c t^{79}$ constituted a privative clause, which protected the tribunal from review unless its decision was patently unreasonable. ${ }^{80}$

This standard of review is in accord with the Supreme Court of Canada's ruling in Mossop, ${ }^{81}$ wherein La Forest J. examined the C.H.R.A., which did not contain a privative clause. He wrote that courts have deferred to administrative tribunals' reasonable decisions on questions of law where those tribunals are protected by a privative clause. ${ }^{82} \mathrm{He}$ also noted that courts have also deferred to tribunals not so protected, for reasons of relative expertise, but observed that, in relation to general questions of law such as the one in question in that case:

R.S.N.B. 1973, c. H-11.

Ross, supra note 4 at D/252 (N.B.Q.B.).

Ibid. at D/254-55.

Section 21(1) states: All orders and decisions of a Board of Inquiry are final and shall be made in writing, together with a written statement of the reasons therefor, and copies of all such orders, decisions and statements shall be provided to the parties and to the Minister [emphasis added]. Ross, supra note 4 at D/253 (N.B.Q.B.).

Ibid. at 674-75. 
[T]he position of a human rights tribunal is not analogous to a labour board (and similar highly specialized bodies) to which, even absent a privative clause, the courts will give a considerable measure of deference on questions of law falling within the area of expertise of these bodies because of the role and functions accorded to them by their constituent Act in the operation of the legislation... 83

and,

The superior expertise of a human rights tribunal relates to fact-finding and adjudication in a human rights context. It does not extend to general questions of law.... They [courts] must, therefore, review the tribunal's decisions on questions of this kind on the basis of correctness, not on a standard of reasonability. ${ }^{\text {st }}$

In the face of a privative clause, the standard of review is to be determined by asking "whether the privative clause in the context of the legislation reflects legislative intention to limit judicial supervision by the courts." ${ }^{85}$ Given that the human rights codes of other jurisdictions vary with regard to the ability to appeal or review a Board of Inquiry/Tribunal decision, ${ }^{86}$ the wording of the New Brunswick statute is of relevance. While in Berg, Lamer C.J. applied a standard of correctness, he did note that there was no reason why deference should be given to the B.C. Council on questions of law. Here, on its face, s. 21(1) appears to reflect the legislative intent of limiting supervision by the courts. Thus the standard of review in this case is one of reasonableness of findings of fact and law, and not correctness. The exception is that the jurisdiction of the human rights Board of Inquiry is limited in one crucial respect: it can expect no curial deference with respect to consitutional decisions. ${ }^{87}$

\section{Ibid. at 675-76.}

Ibid.

Mossop, supra note 10 at 675 , La Forest J.

The B.C. Human Rights Act, S.B.C. 1984, c. 22, contains no privative clause but in s. 18(1) contemplates "judicial review"; the Alberta Individuals Rights Protection Act, R.S.A. 1980, c. I-2, expressly conveys extensive supervisory powers to the Courts in s. 33(4): "The Court may confirm, reverse or vary the order of the board and make any order that the board may make under s. 31"; the Saskatchewan Human Rights Code, S.S. 1979 c. S-24.1. s. 32(1) provides for appeals to the Court of Queen's Bench on questions of law; the Manitoba Human Rights Code, S.M. 1987-88 c. 45, expressly limits action to judicial review in s. 50(1); the Ontario Human Rights Code, R.S.O. 1990, c. H-19, expressly grants appeals to the Divisional Court in s. 42(1); the Nova Scotia Human Rights Act, R.S.N.S. 1989, c. 214 , provides for appeal in s. 36(1) on questions of law; Newfoundland provides for appeals to the Trial Division requiring leave on fact or mixed fact and law grounds, Human Rights Code, R.S.N. 1990, c. M-14, s. 30; Quebec has a unique and broader Charter of Human Rights and Freedoms, L.R.Q. 1977, c. C-12, and different legislative scheme wherein the Commission applies to a tribunal for an injunction for failing to comply with its recommendation (at S. 80); P.E.I. has a unique legislative scheme wherein the Commission makes recommendations to the Minister who may issue whatever order he considers necessary. See Human Rights Act, R.S.P.E.I. 1988, c. H-12, ss. 27, 28. 


\section{c. Excess of Jurisdiction}

The Court of Queen's Bench quashed clause 2(d) of the Board Order by holding that the Board exceeded its jurisdiction in constraining Mr. Ross' activities outside of the classroom while he was holding a non-teaching position. ${ }^{88}$ Creaghan $\mathrm{J}$. framed the issues on appeal as follows: "Did the Board of Inquiry act within its jurisdiction?" and "Did the order of the Board of Inquiry violate the rights of the applicant under the Charter of Rights and Freedoms so as to be of no force and effect?" ${ }^{89}$ Creaghan J. interpreted the Board of Inquiry's decision as finding that the School Board was at fault for continuing to employ Ross as a teacher in the classroom. He held that "[t]here was no jurisdiction in the Board of Inquiry to make an order that directed the School Board to place restrictions on Malcolm Ross' activities outside the classroom in the event that he was no longer employed by the School Board as a teacher in the classroom." 90

The issue is: Was the Board of Inquiry's order 2(d) based upon a reasonable finding of fact or law by the Board of Inquiry? It is submitted that the Board of Inquiry's ability to curtail Mr. Ross' extra-curricular activities is dependent upon its finding of fact. If the Board found that the creation of a poisoned educational environment was linked to Ross' employment with the School Board in amy capacity, then it acted within jurisdiction. If it found that the discrimination was linked only to Ross' teaching position, then Justice Creaghan was correct, as the Board can only order such acts so as to "effect compliance with the Act," and to "rectify any harm caused by the violation."91 One can argue that the Board of Inquiry impliedly found that Ross' employment in any capacity would continue to foster a poisoned environment. However, given the contradiction in the Board of Inquiry's order, and its analysis of role modelling obligations of teachers, Creaghan J.'s analysis is not without some persuasion.

\section{d. Freedom of Expression}

Thereafter in obiter, Creaghan J. commented that clause 2(d) of the Board's order also violated Ross' freedom of expression and was not proportional nor rationally connected to the objective of s. 5 of the Act, within the meaning of $s$. 1 of the Charter. ${ }^{22}$

Ross, supra note 4 at D/255 (N.B.Q.B.).

Ibid. at $\mathrm{D} / 252$.

Ibid. at $\mathrm{D} / 253$ [emphasis added].

Supra note 76, s. 20(6.2).

Ross, supra note 4 at D/255 (N.B.Q.B.). Section 5 of the New Brunswick Human Rights Act states that, "No person, directly or indirectly, alone or with another, by himself or by the interposition of another, shall ... (b) discriminate against any person or class of persons with respect to any accommodation, services or facilities available to the public."

Section 1 of the Charter provides that: "The Canadian Charter of Rights and Freedoms guarantees the rights and freedoms set out in it subject only to such reasonable limits prescribed by law as can be demonstrably justified in a free and democratic society." 
If we assume that the Board of Inquiry acted within jurisdiction, then the preliminary issue of whether a judicial/quasi-judicial administrative order is subject to constitutional attack must be examined. In Retail, Wholesale \& Department Union, Local $580 \mathrm{v}$. Dolphin Delivery Ltd., ${ }^{93}$ the Supreme Court of Canada held that court orders are not susceptible to Charter scrutiny within the meaning of s. 32 of the Charter. ${ }^{94}$ McIntyre J. wrote, "I cannot equate for the purposes of Charter application the order of a Court with an element of governmental action." 95 Judges and courts are bound by the Charter, in the sense that they must apply its provisions in deciding cases that come before them. However, in Slaight Communications Inc. v. Davidson, ${ }^{96}$ the Court held that the Charter applied to the decision of an adjudicator made pursuant to his statutory authority. An adjudicator who exercises delegated powers does not have the power to make an order that would result in a Charter infringement. Similarly, the orders of human rights boards/tribunals must comply with the Charter. Yet, it is their statutory base that should be examined in a constitutional challenge.

It is submitted that the proper question on review is: "do the provisions of the enabling statute, constituting the statutory basis of the order (in this case, sections 5 and 20(6.2) of the New Brunswick Human Rights Act), violate Mr. Ross' s. 2(b) Charter right of freedom of expression?" Creaghan J. appeared to believe that they did. Applying the Oakes test, he stated that clause 2(d) of the order was not rationally connected to the objective of s. 5 and that the impairment of the Charter rights was too great to be reasonable and demonstrably justified. ${ }^{97}$

In regard to clauses 2(a),(b) \& (c) of the Board's order, Creaghan J. held that while these provisions violated Mr. Ross' constitutional rights, they were reasonable limits on the same. ${ }^{98}$

\section{Decision of the Court of Appeal}

\section{a. Poisoned Educational Environment and Political Correctness}

The Court of Appeal quashed the order directing the Board to terminate Ross, thus leaving no part of the original Board of Inquiry order standing. Hoyt C.J.N.B. held that the order unreasonably violated Ross' freedom of expression. He held that the Board of Inquiry:

(1986), 33 D.L.R. (4th) 174 (S.C.C.) [hereinafter Dolphin Delivery]. See Royer v. Migneault (1988), 13 Q.A.C. 39, 50 D.L.R. (4th) 345, 32 C.R.R. 1 (Que. C.A.), which followed Dolphin Delivery in considering a constitutional challenge to a judge's remarks.

Section 32 of the Charter provides that:

(1) This Charter applies (a) to the Parliament and government of Canada in respect of all matters within the authority of Parliament including all matters relating to the Yukon Territory and Northwest Territories; and (b) to the legislature and government of each province in respect of all matters within the authority of the legislature of each province.

Dolphin Delivery, supra note 93 at 196.

[1989] 1 S.C.R. 1038.

Ross, supra note 4 at D/255 (N.B.Q.B.).

Ibid. 
[F]ound that Mr. Ross did not attempt to further his views in the classroom. No connection was made between Mr. Ross' expressed views and any offensive remarks directed to Miss Attis and Mr. Lambert. Remarks made by school children in the playground of another school are, in my opinion, too tenuous to found such a restriction. If the evidence disclosed that Mr. Ross' remarks sparked or even were used to legitimize the offensive remarks made in the school yard, perhaps the sanction in the order would be appropriate ... [t]he evidence does not disclose that Mr. Ross ever used or contended that he was free to use his teaching position to further his religious views.... To hold otherwise would, in my view, have the effect of condoning the suppression of views that are not politically popular at any given time.99

Political correctness is a term that is often used to define unacceptable intrusions on free speech, particularly in the context of prejudicial expression against groups such as women, racial and religious minorities, disabled persons, and Aboriginal Canadians. While it has been generally accepted that free speech has limits, such as in the context of defamation and slander, similar respect for groups rather than for individuals has been rejected. Mr. Justice John Sopinka is quoted as citing, in a public address, the demand for "political correctness" from equality-seeking groups as one of "four major threats" to freedom of expression in Canada and as a potential influence on judicial decision making. ${ }^{100}$ Sheila McIntyre, on the other hand, vents a scathing commentary against critics of political correctness in her article, "Backlash Against Equality":

Critics of so-called political correctness take the position that freedom of expression should not be curbed, particularly within the university, even in the cause for equality; that true scholarship is not and should not be political; that academic and cultural standards emerge from objectively determinable values or transcendent universal truths; and that to centre liberal education on the study of the greatest artists, thinkers and statesmen of Western culture is not to promote a political agenda but to educate students in the best that (the best) civilization has to offer. ${ }^{\text {.01 }}$

With respect, it is submitted that political correctness is not the issue in the Ross case; rather the issue is one of the substantive creation of a poisoned educational environment. There is an obligation to restrict discriminatory speech and acts in the context of the provision of public services, employment, tenancies and public notices. Mr. Ross is free to espouse his prejudicial and discriminatory views so long as they do not create such an environment both at the school where he teaches, and in the larger educational system that provides public services. Albeit, it may be difficult for Mr. Ross to hold any position with the School Board given the extremity of his viewpoint and his repeated publication of the same throughout his community, including the community wherein students of his school reside.

The creation of a poisoned educational environment does not require proof that other students have discriminated against minority students, but only that a racially hostile

Ross, supra note 4 at D/178 (N.B.C.A.) [emphasis added].

S. McIntryre, "Backlash Against Equality: The 'Tyranny' of the 'Politically Correct'" (1993) 38:1 McGill L.J. 1 at 13, 42n. McIntyre was citing M. Fitz-James, "Judges Shouldn't Be Cowed by 'Political Correctness': Sopinka" The Lawyers Weekly (1 May 1992) 2.

McIntyre, ibid. at 35. 
educational environment has been created for minority students. In Canada (Human Rights Commission) v. Taylor, ${ }^{102}$ the Supreme Court of Canada, in upholding the constitutionality of s. 13(1) of the C.H.R.A., which deals with telephone communication of hate messages, noted that the messages had the potential to convince listeners that certain persons are inferior because of the identifiable group to which they belong. Thus, this persuasive process could result in the increase of violations of the C.H.R.A. The Janzen definition of harassment transposed into the Ross context would be: "unwelcome conduct of a [racial/religious] nature that detrimentally affects the [educational] environment or leads to adverse [education]-related consequences for the victims of harassment. It is ... an abuse of power." ${ }^{103}$ The Board of Inquiry made the finding of fact that the complainant established a prima facie case of discrimination within the meaning of this definition.

As an appellate court, the Court of Appeal, in this instance, was to give deference to reasonable findings of law and fact made by the Board of Inquiry, albeit in the absence of a Charter challenge. The standard of review should not have been one of correctness. Therefore, it is respectfully submitted that the Court of Appeal erred in overturning the reasonable findings of fact made by the Board of Inquiry, namely that the off-duty public statements and writings of Ross, continuing over many years, contributed to the creation of a poisoned educational environment at his school, particularly given the role-modelling aspect of a teacher's position. ${ }^{104}$ Hoyt C.J.N.B.'s criticism of the evidentiary evaluation of the evidence by the Board of Inquiry, respecting offensive comments at various playgrounds, was an over-extension of his appellate function. It is submitted that the Board's finding of fact was not patently unreasonable, perverse or capricious, and that in effect, the Court of Appeal failed to accept that a hostile educational environment constitutes discrimination as delineated by the Supreme Court of Canada in Janzen.

\section{b. Freedom of Expression}

As for the validity of the Court of Appeal's reasoning regarding freedom of expression, it is submitted that an issue arises as to whether or not Charter arguments were properly made before the Court of Queen's Bench, sitting in an appellate capacity, given that none were advanced before the Board of Inquiry. The Supreme Court of Canada has held that administrative bodies can play a role in the determination of constitutional questions and can be of assistance in compiling the record. ${ }^{105}$ Allowing Ross to present constitutional arguments at an appellate level ran the risk that the proper constitutional facts may not have been adduced, ${ }^{106}$ and that the ability of parties to adduce different or further evidence had passed.

\footnotetext{
[1990] 3 S.C.R. 892 [hereinafter Taylor].

See supra note 5 at 1284 for the Janzen definition of sexual harassment.

Ross, supra note 4 at D/357 (N.B. Bd. Inq.).

See Cuddy Chicks LId. v. Ontario (Labour Relations Board), [1991] 2 S.C.R. 5, 81 D.L.R. (4th) 121, 50 Admin. L.R. 44 [hereinafter Cuddy Chicks]; Tetreault-Gadoury v. Canada (Employment \& Immigration Commission), [1991] 2 S.C.R. 22, 81 D.L.R. (4th) 358, 50 Admin L.R. 1. 
Assuming, however, that a proper factual background for Charter purposes had been established, scrutiny of ss. 5 and 20(6.2) of the New Brunswick Human Rights Act dictates the following questions:

Is the impugned expression subject to Charter protection?

Are the legal consequences, of being fired or restricted in employment for creating a poisoned educational environment, an infringement of a person's s. 2(b) freedom of expression rights?

If so, does its limitation by the statute constitute a reasonable limit within s. 1 of the Charter?

Thus the question is not the one which was asked by Hoyt C.J.N.B.:

The issue is whether an individual's freedom of expression can prevail against the fear that there will be a public perception that Mr. Ross' discriminatory remarks directed against a religious or ethnic minority are being condoned. ${ }^{107}$

It is submitted that the expressions in question do deserve the protection of s. 2(b) of the Charter. Although they are distasteful and anti-Semitic, the publications attempt to convey meaning, have expressive content and therefore prima facie fall within the scope of the guarantee. ${ }^{108}$ Freedom of expression was entrenched in the Charter to ensure that everyone can manifest thoughts, opinions, beliefs and expressions of the heart and mind, however unpopular, distasteful or contrary to the mainstream. Activities cannot be excluded from the scope of the guaranteed freedom on the basis of content or meaning conveyed. ${ }^{109}$ In Toylor ${ }^{110}$ the Court confirmed that expression is protected, regardless of content, as long as it is not communicated in physically violent forms.

However, it is respectfully submitted that the New Brunswick Court of Appeal failed to reconcile its finding with the Supreme Court decisions in Taylor and in Keegstra, and relied expressly upon $R$. v. Zundel. "' In the Keegstra case, a high school teacher

Ross, supra note 4 at D/177 (N.B.C.A.).

See $R$. v. Keegstra, [1990] 3 S.C.R. 697 [hereinafter Keegstra]. All communications which convey or attempt to convey meaning are protected under "freedom of expression" unless the physical form of the communications excludes protection (e.g. a violent act). The underlying values and principles of the freedom are: that "seeking and attaining truth is an inherently good activity"; that "participation in social and political decision-making is to be fostered and encouraged"; and that "diversity in forms of individual self-fulfilment and human flourishing ought to be cultivated in a tolerant ... environment ..." (ibid. at 728). Its purpose extends to the protection of minority beliefs which the majority regards as wrong or false. See Irwin Toy Ltd. v. Quebec (A.-G.), [1989] 1 S.C.R. 927; Re Ontario Film and Video Appreciation Society and Ontario Board of Censors (1983), 5 D.L.R. (4th) 766; R. v. Edwards Books and Art Lid., [1986] 2 S.C.R. 713.

See $R$. v. Butler, [1992] I S.C.R. 452 [hereinafter Butler].

Supra note 102.

[1992] 2 S.C.R. 731 [hereinafter Zundel]. For academic comment, see B. Elman \& E. Nelson, "Distinguishing Zundel and Keegstra" (1993) 4:3 Constit. Forum 71; V. Ramraj, "Keegstra, Butler and Positive Liberty: A Glimmer of Hope for the Faithful" (1993) 51 U.T. Fac. L. Rev. 304; M. Valois, "Hate Propaganda, Section 2(b) and Section 1 of the Charter: A Canadian Constitutional 
was charged with the criminal offence of unlawfully promoting hatred against an identifiable group by communicating anti-Semitic statements to his students. The Supreme Court of Canada upheld the section as constitutional. Dickson C.J., for the majority, held that communications which wilfully promote hatred against an identifiable group were protected by freedom of expression as entrenched in s. 2(b) of the Charter and thereby confirmed that the constitutional guarantee is broad in nature. ${ }^{112}$ But, the Charter also guarantees equality rights and non-discrimination rights, ${ }^{113}$ as well as multicultural rights. ${ }^{114}$ Dickson C.J. relied upon these sections in holding that the impugned section was a reasonable limit on free expression. ${ }^{115} \mathrm{He}$ found that Canada's commitment to the values of equality and multiculturalism in ss. 15 and 27 strengthen the "legitimacy and substantial nature of the government [legislative] objective."116 The Court also referred to the work of many study groups, historical knowledge of the potentially catastrophic effects of the promotion of hatred, and international commitments to eradicating hate propaganda. In finding that the section met the proportionality test, Dickson C.J. referred to the objective of protecting target group members and of fostering harmonious social relations in a community dedicated to equality and multiculturalism. ${ }^{117}$

In contrast, Zundel dealt with the publication of hate literature. The Supreme Court considered the constitutionality of s. 181 of the Criminal Code. ${ }^{118}$ McLachlin J., for the majority, confirmed the broad purposive interpretation of the freedom guaranteed in s. 2(b). The Court held that s. 181 infringed the guarantee of freedom of expression because s. 2(b) of the Charter protects the right of a minority to express its view, however unpopular. However, contrary to Keegstra, the Court held that the section was too broad to constitute a reasonable limit under s. 1 of the Charter.

It is submitted that Professor Elman and Ms. Nelson are correct in arguing that

Dilemman (1992) 26 R.J.T. 373.

Supra note 108 at 730.

Section 15 of the Charter, supra note 3 states: "Every individual is equal before and under the law and has the right to equal protection and equal benefit of the law without discrimination and, in particular, without discrimination based on race, national or ethnic origin, colour, religion, sex, age or mental or physical disability."

See ibid., s. 27: "This Charter shall be interpreted in a manner consistent with the preservation and enhancement of the multicultural heritage of Canadians."

Keegstra, supra note 108 at 755-58.

Ibid. at 758. For commentary on the use of interpretative clauses, see S. Chotalia, "The Canada Clause That Was: How Courts Use Interpretative Clauses" (1993) 4:2 Constit. Forum at 38.

Keegstra, ibid. at 769.

R.S.C. 1985, c. C-46. Section 181 stated, "Everyone who wilfully publishes a statement, tale or news that he knows is false and that causes or is likely to cause injury or mischief to a public interest is guilty of an indictable offence and liable to imprisonment for a term not exceeding two years." 
Justice McLachlin's use of the Keegstra decision (a decision in which she dissented) as a benchmark for evaluation of the false news provision [in Zundel], confirms the constitutionality of the hate propaganda provision and the validity of the analysis employed in Keegstra itself. ${ }^{119}$

It is further submitted that the authors are also correct in noting that the legislation in Zundel had no currency and was not pressing and substantial. ${ }^{120}$ Finally, as they observe, the provision in Keegstra was more narrowly drafted, with special statutory defences, as compared to the broad offence of wilful publication of false news. ${ }^{121}$

The argument for the applicability of Keegstra is further strengthened by observing that the reasoning of Keegstra evolved out of a criminal law context. The same logic becomes even more compelling in the context of human rights legislation. While criminal law is punitive and penal in nature, human rights legislation is remedial and "quasi-constitutional." The vindication of the Criminal Code offence of wilful promotion of hatred more forcefully bolsters anti-discrimination legislation.

Indeed, the Supreme Court in Taylor upheld the C.H.R.A. provisions proscribing the communication of hate messages as constitutionally valid. The Court held that while the sections did infringe upon freedom of speech, they were reasonable limits designed to prevent the spread of prejudice and to foster tolerance and equality in the community, and that the sections were sufficiently precise. ${ }^{122}$ Dickson C.J. held for the majority that Parliament's objective of promoting equal opportunity unhindered by discriminatory practices, and thus of preventing the harm caused by hate propaganda, was of sufficient importance to warrant overriding a constitutional freedom. ${ }^{123}$ Hate propaganda presents a serious threat to society. It undermines the dignity and self-worth of target group members and, more generally, contributes to disharmonious relations among various racial, cultural and religious groups, consequently eroding the tolerance and open-mindedness that must flourish in a multicultural society which is committed to the idea of equality. The international commitment to eradicate hate propaganda and Canada's commitment to the values of equality and multiculturalism, enshrined in ss. 15 and 27 of the Charter, magnify the weightiness of Parliament's objective in enacting s. 13(1). ${ }^{124}$ This reasoning is equally persuasive in dealing with the New Brunswick Human Rights Act and the creation of a poisoned educational environment, considered in Ross. While the evidentiary evaluation necessarily examines a broad range of conduct, the sections are sufficiently precise and codify pressing and fundamental objectives.

Second, the Court in Taylor held that s. 13(1) of the C.H.R.A. was proportionate to the government's objective. The section was rationally connected to the "aim of

119 Elman \& Nelson, supra note 111 at 77. See also B.P. Elman, "Combatting Racist Speech: The Canadian Experience" (1994) 32 Alta. L. Rev. 623 at 645-49.

$120 \quad$ Ibid. at 72-73.

121 Ibid. at 74-75.

122 Supra note 102 at 938-39 (Dickson C.J.).

123 Ibid. at 917-21.

124 Ibid. at 919-20. 
restricting activities antithetical to the promotion of equality and tolerance in society." ${ }^{125}$ "[W]hen conjoined with the remedial provisions of the [C.H.R.A.], s. 13(1) operates to suppress hate propaganda and its harmful consequences...." ${ }^{126}$ It also reminds Canadians of our fundamental commitment to equality of opportunity and the eradication of racial and religious intolerance. The fact that the international community considers such laws to be an important weapon against racial and religious intolerance strongly suggests that $s$. 13(1) cannot be viewed as ineffectual. The guarantee of freedom of expression was held not to be unduly impaired by s. 13(1). ${ }^{127}$ The section was not overbroad or excessively vague. In the context of Ross, the potential restriction of speech is also limited, in this case to the provision of public services.

The Court in Taylor noted that "the [impugned] section furthers a government objective of great significance and impinges upon expression exhibiting only tenuous links with the values underlying the freedom of expression guarantee." ${ }^{128}$ Hate propaganda contributes little to the aspirations of Canadians or Canada in the quest for truth, the promotion of individual self-development or the protection and fostering of a vibrant democracy where the participation of all individuals is accepted and encouraged. "Moreover, operating in the context of the procedural and remedial provisions of the [C.H.R.A.], s. 13(1) plays a minimal role in the imposition of moral, financial or incarcerating sanctions, the primary goal being to act directly for the benefit of those likely to be exposed to the harms caused by hate propaganda." ${ }^{129}$ These same arguments are applicable to support the constitutionality of the New Brunswick Human Rights Act.

In summary, it is submitted that, given the quasi-constitutional nature of human rights legislation and laws; ${ }^{130}$ the pressing and substantial need to eradicate discrimination, including harassment; the work of innumerable study and research groups on discrimination and racial and sexual harassment; the historical knowledge of how discrimination infringes upon the rights of individuals to participate fully and equally in Canadian society; the harm that discriminatory conduct causes to the dignity of minorities in Canada, and the resultant harm that society bears; international commitments to promoting human rights values; ${ }^{131}$ and ss. 15, 27 and 28 of the Charter, the human rights statute and the remedial order in Ross do constitute a reasonable limit on s. 2(b) rights. In short, the dissenting reasons of Ryan J.A. regarding the termination order in Ross are the most persuasive and logical:

Ibid. at 923.

Ibid. In Butler, supra note 109, the Court, in dealing with the constitutionality of obscenity provisions, held that harm to human dignity and to women's equality caused by obscene materials justified their criminal proscription and the resulting limit on freedom of expression.

Taylor, ibid. at 938-39.

Ibid. at 939-40.

Ibid. at 940.

Supra note 9.

E.g. The International Bill of Human Rights, U.N.G.A. Res. 217A(III) (10 Dec. 1948). 
The wrong is in the continued discrimination publicly promoted by Ross, a public servant, as a role model to children. He is known as an elementary teacher whether in the classroom or outside of it where he is promoting discrimination and prejudice. ${ }^{132}$

Ryan J.A. later held that:

Ross remains free to leave public employment and engage fully in the exercise of his freedom of speech and religion without restraint. A restriction, therefore, that he cease his discriminatory conduct is a justifiable infringement. It is not absolute." 133

Ryan J.A. held that the Board's finding of discrimination was unassailable. While the eradication of a poisoned work or educational environment through the auspices of human rights statutes may infringe upon free speech rights, such eradication must be found to be a reasonable limit within the meaning of $s$. 1 of the Charter, and such a result is in keeping with the Supreme Court decisions of Taylor, Keegstra, Butler and even Zundel.

\section{CONCLUSION}

It is submitted that civil and remedial human rights sanctions for the creation of a poisoned educational environment, on the basis of race, religion, ancestry or sex, constitute reasonable limits on free speech.

How then do universities and schools cope with these issues?

\section{EDUCATIONAL INSTITUTIONS AND POISONED EDUCATIONAL ENVIRONMENT SEXUAL HARASSMENT}

\section{A. SEXUAL HARASSMENT POLICIES}

The Ross case foreshadows complaints against poisoned environments on the basis of gender discrimination. To deal with such complaints, most educational institutions, particularly Canadian universities, have general policies against sexual harassment. ${ }^{134}$ The policies cover both quid pro quo and poisoned educational environment harassment. For example, the University of Alberta's policy ${ }^{135}$ accepted the definitions adopted by the Alberta Human Rights Commission and by the Canadian Association of University Teachers (hereinafter referred to as C.A.U.T.). The Alberta Human Rights Commission presently defines sexual harassment as:

\footnotetext{
132 Ross, supra note 4 at D/181 (N.B.C.A.).

133 Ibid. at D/182 [emphasis added].

134 The rampant and pervasive nature of sexual harassment in Canadian universities has been the recent subject of much discussion amongst both students and educators. See e.g. E. Tate, "Harassment Drives Students Out, Says Retired Professor" C.A.U.T. Bulletin (May 1994) 2. 
[A]ny unwelcome behaviour which is sexual in nature and directly or indirectly, adversely affects, or threatens to affect, a person's job security, prospects of promotion or eamings, working conditions, or opportunity to secure a job, living accommodations, or any kind of public service. Sexual harassment is usually an attempt by one person to exercise perceived power over another. ${ }^{136}$

The C.A.U.T. guidelines on Professional Ethics and Professional Relationships are as follows:

Sexual advances, requests for sexual favours, and other verbal or physical conduct of a sexual nature constitute sexual harassment when

a) submission to such conduct is made either explicitly or impliedly a term or condition of an individual's employment, academic status or academic accreditation,

b) submission to or rejection of such conduct by an individual is used as the basis of employment, academic status or academic accreditation decisions affecting such individual[s], or

c) such conduct has the purpose or effect of unreasonably interfering with an individual's work or academic performance or creating an intimidating, hostile or offensive working or academic environment. ${ }^{137}$

The Alberta Department of Education sexual harassment policy refers to the law of sexual harassment as set out in Janzen and Robichaud and gives examples of such behaviour. $^{138}$

This survey of sexual harassment policies of universities, university associations, and education departments confirms that such institutions are attempting to sanction sexual harassment in all of its forms.

Alberta Human Rights Commission, Defining Sexual Harassment (Policy Statement 92-03-13) at 1.

137 "Policy Statement on Professional Ethics and Professional Relationships" in R.W. Kerr et al., eds., C.A.U.T. Handbook of Policy Statements and Model Clauses, 4th ed. (Canada: Canadian Association of University Teachers, 1986) at 39.

Alberta Department of Education, Policy Directive 8-12 (23 February 1993). It is applicable to all provincial government departments. This policy states that sexual harassment can take many forms, from the subtle to the overt. Examples include: suggestive remarks or gestures; compromising invitations or requests; verbal abuse; display of sexually offensive materials; unwelcome leering and whistling; sexual jokes which cause awkwardness or embarrassment; unwelcome enquiries or comments about an individual's sex life; unwelcome remarks about a person's physical attributes or appearance; touching, patting, pinching or other unwelcome physical contact; outright demands for sexual favours; physical assault or indecent exposure. The policy confirms that such conduct is a violation of human rights laws and provides for confidential investigation of complaints. It outlines roles and responsibilities of staff and Ministers, and confirms penalties: the harasser may face a reprimand, a suspension without pay, or dismissal. 


\section{B. CONFLICTS WITH ACADEMIC FREEDOM}

However, educational institutions, particularly universities which are on the cutting edge of knowledge, are bastions of the search for truth and justice. This mandate seems, by its very nature, to imply minimal restrictions upon speech.

This role appears to conflict at times with the role of universities to be at the forefront of social change and to demonstrate their commitment to equity and fairness. Not only are educational institutions bound by the law, but they also have an additional moral obligation to provide leadership in human rights issues. Educational institutions must provide education within a humanistic context wherein gender and race, inter alia, do not create a barrier to learning. In this context, as in Ross, some limitations on free speech are essential. ${ }^{139}$

Undoubtedly, precise line-drawing is difficult. The tension manifests itself in the policies of schools and universities. A recent example involves reaction to the Ontario Government's Framework Regarding the Prevention of Harassment and Discrimination in Ontario Universities. ${ }^{140}$ C.A.U.T.'s resolution regarding academic freedom and sexual harassment ${ }^{141}$ and the Canadian Civil Liberties Association position ${ }^{142}$ called upon the Ontario government to withdraw the document. C.A.U.T. agreed with the government that sexual, racial or other harassment as prohibited by human rights codes should not be tolerated in Canadian universities; "academic decisions should not be tainted by prejudice and ... the university should provide a model for society in this area." ${ }^{143}$ C.A.U.T. also agreed that universities should take positive action to eliminate such harassment, and in particular, should "educate their students and staff about the law, the reasons for it, and the need to obey it."144 However, C.A.U.T. alleged that the government had failed to consider how its framework would affect academic freedom, and that it used vague and imprecise language which could be used "by the enemies both of equality and academic freedom to subvert the progress towards equality

In the American context, see C.A. MacKinnon, Toward a Feminist Theory of the State (Cambridge: Harvard University Press, 1989) at 204-205 (arguing that assumptions underlying the First Amendment "do not apply to the situation of women"); J.P. Byme, "Racial Insults and Free Speech Within the University" (1991) 79 Geo. L.J. 399, wherein he argues that orthodox views regarding the free speech rights of students at universities are inadequate; P.B. Hodulik, "Prohibiting Discriminatory Harassment by Regulating Student Speech: A Balance of FirstAmendment and University Interests" (1990) 16 J.C. \& U.L. 573.

Ontario Ministry of Education and Training, Framework Regarding the Prevention of Harassment and Discrimination in Ontario Universities (Toronto: The Ministry, 1994). The govemment issued this framework document to remind universities that they were bound by the Ontario Human Rights Code and to determine if they had appropriate human rights policies in place. See "CAUT calls on Ontario gov't to withdraw 'framework'" C.A.U.T. Bulletin (June 1994) 1. C.A.U.T. adopted the resolution at a general meeting April 29 - May 1, 1994. Universities (15 March 1994) in infra note 159 at In.

143 Supra note 141 at 1. C.A.U.T. passed a separate resolution expressing support for the efforts of its member university faculty associations in developing and negotiating effective norms and processes to prevent harassment and discrimination. 
and the free discussion of ideas." 145 In effect, C.A.U.T. was expressing the frustration of being unable to precisely define the balance between protection against harassment and safeguarding academic freedom. ${ }^{146}$

\section{EXAMPLES OF RECENT CONFLICTS BETWEEN PROSCRIBING DISCRIMINATION AND ACADEMIC FREEDOM}

A number of recent occurrences demonstrate the ever present conflict between proscribing discrimination and freedom of speech. For example, a Canadian associate professor of mathematics at the University of New Brunswick published his controversial views in a student newspaper, stating that women who visit men's rooms at night should not be surprised if date rape occurs. ${ }^{147}$

The Yaqzan incident resulted in the issuance of a joint statement by C.A.U.T. and the University in which they reemphasized their commitment to "work together to maintain a positive atmosphere for learning and study at the University, based on respect for all persons and free intellectual inquiry based on an honest search for

Ibid. See also A.A. Borovoy, When Freedoms Collide: The Case for Our Civil Liberties (Toronto: Lester \& Orpen Dennys Ltd., 1988). A number of American universities have passed antidiscrimination and harassment policies including speech codes which are being successfully legally challenged: see e.g. Doe v. University of Michigan, 721 F. Supp. 852 (E.D. Mich. 1989), in which a policy on discrimination and harassment of students was held to be unconstitutionally overbroad and vague and a violation of the due process clause; however, the court also held that a more narrowly drawn regulation might be upheld. The impugned policy prohibited "behaviour, verbal or physical, that stigmatizes ... an individual on the basis of race, ethnicity, religion, sex, sexual orientation, creed, national origin, ancestry, age, marital status, handicap or Vietnam-era veteran status," (ibid. at 856) and poses some kind of "threat" or "interfere[s]" with a person's university endeavours (ibid.). Much polemical literature on political correctness followed the creation of such policies; see e.g. D. Bromwich, Politics by Other Means: Higher Education and Group Thinking (New Haven: Yale University Press, 1992); S. Fish, There's No Such Thing as Free Speech, and It's a Good Thing. Too (New York: Oxford University Press, 1994); N. Hentoff, Free Speech for Me - But Not for Thee: How the American Left and Right Relentlessly Censor Each Other, 1st ed. (New York: Harper Collins, 1992); R. Hughes, Culture of Complaint: The Fraying of America (New York: Oxford University Press, 1993).

Another criticism was that the government framework failed to explicitly support academic freedom (C.A.U.T., ibid.). The third criticism was that the government "failed to distinguish between the teaching situation in universities and that in the primary and secondary schools or between the work of academic staff and other employment situations." (ibid. at 9). University educators teach a largely adult and voluntary clientele of students, and also undertake as part of their contractual obligations research, scholarly activity and community duties (ibid.).

Matin Yaqzan. See "Closing Mouths Closes Minds" The Globe and Mail (13 November 1993) D6; K. Cox, "Professor Banished for Views on Rape" The Globe and Mail (12 November 1993) A1; "Date Rape Comments Cause Campus Furor" The Globe and Mail (9 November 1993) A6; B. Bergman \& K. Honey, "Conflict on Campus" Maclean's (29 November 1993); C. Trueheart, "Canadian Professor Flunks PC Test: Uproar Over Article on Date Rape, Promiscuity Leads to Suspension" The Washington Post (1 December 1993) Cl. The university temporarily suspended Yaqzan with pay, pending an investigation of the complaint of sexual harassment by the students' union. Thereafter he was cleared and reinstated. Eventually, however, he was offered a severance package for early retirement, which he accepted. 
truth." 148 Inherent in this statement is the tension between free speech and restrictions on the same. Balancing speech to ensure compliance with human rights codes and discrimination-free environments is not an easy task. Schrank argues:

Of course no right is absolute. Certain kinds of hateful utterances are proscribed by legislation. Academic freedom exists within this legal context.... The difficulty of defining categories of prohibited speech without impinging on speech that should be unfettered and free is obvious. The inevitable ambiguity and openness of the terms defining a prohibition have the potential for mischief, for generating complaints against speech that expresses unpopular ideas. Moreover, regulation may provide the green light to students, faculty, and administrators - driven by personal conviction or political need or pure malice - to attempt to silence those who express views with which they disagree. ${ }^{149}$

Other recent incidents include an American psychiatrist/psychologist who attempted to deliver a lecture at Queen's University wherein he wished to propound his theory that adults giving evidence of their childhood sexual abuse are not reliable witnesses. He was unable to deliver the lecture due to the constant jeering and shouting of students and others. ${ }^{150}$ In yet another example, a Canadian professor attempted to maintain that intelligence was based upon race - he theorized that Asians as a race have superior intelligence to that of whites and blacks. ${ }^{\text {s1 }}$

\section{LEGAL ANALYSIS — POISONED EDUCATIONAL ENVIRONMENT}

An analysis of these incidents involves the following inquiries:

First, did the professor's actions constitute sexual harassment through the creation of a poisoned educational environment?

Second, if so, could the professor legitimately raise the defence of academic freedom?

As discussed above, the first inquiry is a factual one to be determined by a Board of Inquiry or Tribunal. The nature and gravity of the conduct will have to be assessed, and the link between the conduct and the creation of the poisoned environment must be evaluated. The necessity of such analysis is accentuated by the incomplete evaluation of these issues in the Board of Inquiry decision of Ross. ${ }^{152}$ In the Yaqzan incident, the statements appeared to condone sexual assault by males upon females, irrespective of the issue of consent; they were published in the student body newspaper; the statements were made by a person in a position of power and authority; but, in contrast to the statements in Ross, these statements appear to have been published on only one occasion. They were no doubt offensive. But did they create or significantly contribute

C.A.U.T. Bulletin (December 1993) at 2. This case was not litigated, as Yaqzan accepted a voluntary severance package.

B. Schrank, "Academic Freedom and the Inclusive University" C.A.U.T. Bulletin (May 1994) 9 at 10.

See "Closing Mouths Closes Minds," supra note 144.

J.P. Rushton, "Race, Brain Size and Intelligence: Another Reply to Cernovsky" (1991) 68:2 Psych.

Rep. 500.

Supra note 4 (N.B. Bd. Inq.). 
to the creation of a hostile or offensive educational environment? As discussed, American jurisdictions are using the "reasonable woman" standard. ${ }^{153}$ While this would be an appropriate standard to use, the difficulty lies in being unable to adduce sufficient evidence. In all cases, counsel should be creative and examine the opportunity to adduce direct, expert, statistical, historical and/or psychological evidence to establish the creation of a poisoned environment. Counsel should also establish the link between the professor's/teacher's role in the institution with the creation of the poisoned educational environment in the institution. But given that frequency of the conduct is an important factor, a finding of the creation of a discriminatory poisoned educational environment could not have been established in this case.

\section{E. ACADEMIC FREEDOM - DEFINITION}

The Supreme Court of Canada has not yet ruled on the extent to which academic freedom could constitute a defence to a human rights violation. References to academic freedom, however, have been made in other contexts. For example, in McKinney ${ }^{154}$ and Dickason v. The Board of Governors of the University of Alberta, ${ }^{155}$ the Supreme Court justified mandatory retirement in the university setting as being a reasonable instance of age discrimination, in part due to the importance of the tenure system and academic freedom. In McKinney, La Forest J. wrote:

Tenure provides the necessary academic freedom to allow free and fearless search for knowledge and the propagation of ideas. Rigorous initial assessment is necessary as are further assessments in relation to merit increases, promotion and the like. But apart from this, and excepting cases of flagrant misconduct, incompetence or lack of performance, strict performance appraisals are non-existent.... The desire to avoid such evaluation ... [reflects] the desire to maximize academic freedom by minimizing interference and evaluation. ${ }^{156}$

La Forest J. also quoted the Ontario Court of Appeal decision with approval:

The policy of tenure in university faculties is fundamental to the preservation of academic freedom. It involves a rigorous assessment by one's peers of academic performance after a probationary period of up to five years. Once tenure is granted, it provides a truly free and innovative learning and research environment. Faculty members can take unpopular positions without fear of loss of employment. ${ }^{17}$

While the Supreme Court did not expand further upon what constitues academic freedom, the generally accepted tenets of academic freedom are as follows:

Supra note 25.

Supra note 2.

(1992), 95 D.L.R. (4th) 439 (S.C.C.) [hereinafter Dickason]. For a criticism of Dickason, see S. Chotalia, "The Supreme Court and Mandatory Retirement: Sanctioning the Status Quo" (1993) 4:3 Constit. Forum 67.

Supra note 2 at $\mathrm{D} / 198$.

Ibid. La Forest J. was quoting from McKinney v. University of Guelph (1988), 9 C.H.R.R. D/4573

at D/4596 (Ont. C.A.). 
the right of academics to teach and to do research ... without regard for prescribed doctrine, and free from political and other interferences...

the right to disseminate the fruits of that teaching and research without adhering to any prescribed doctrine...

the right to criticize one's colleagues, one's employer, the government [without fear of reprisal]...

it [also] involves tenure, or security of employment.... ${ }^{158}$

The purpose of academic freedom is to ensure that the truth, no matter how unpalatable, is discovered and disseminated. But, by its very nature, academic freedom corresponds with the inherent responsibility of promoting truth and producing work free of bias. C.A.U.T. has stated: "[a]cademic freedom carries with it the duty to use that freedom in a manner consistent with the scholarly obligation to base research and teaching on an honest search for knowledge." 159

The interrelationship between academic freedom and bias-free environments have been commented on by many academics. Schrank is correct when she argues that while some may postulate that "academic freedom" and "the inclusive university"160 are oppositional, they actually "exist in a relationship of reciprocity, interconnected and interdependent. The truth is you can't have one without the other." ${ }^{161}$ In other words, pluralism and diversity, by their very nature, vis-à-vis curriculum, interaction between educators and students, and academic work, require academic freedom. Academic freedom itself is contingent upon diversity. ${ }^{162}$ Professor Byrne propounds that scholarship and learning necessarily involve the discipline of speech to improve it: "The university should properly be seen as a distinct social entity, whose commitment to enhancing the quality of speech justifies setting minimum standards for the manner of speech among its members." 163

Supra note 149 at 9 [emphasis added].

C.A.U.T., Reply to the Ontario Government - Academic Staff and the Ontario Government's Framework Document (May 1994). In the context of American universities, the harm of racist or sexist speech has been portrayed as the creation of a hostile environment that denies the target student equal educational opportunity. The American Civil Liberties Union agrees that universities should prohibit "sexually demeaning or derogatory comments ... directed at a specific student or gender [that] have definable consequences for the student that demonstrably hinders his or her learning experiences as a student." A.C.L.U. Policy Guide No. 72, as cited in J.P. Byme, "Racial Insults and Free Speech Within the University," infra note 163 at 36n.

Supra note 149 at 9. "Inclusivity' recognizes and seeks to increase diversity, openness and tolerance within the university in relation to curriculum and to the academic work environment." (ibid.).

lbid.

See E. Said, "Identity, Authority, and Freedom: The Potentate and the Traveller" (1991) as referred to in Shrank, supra note 149.

J.P. Byrne, "Racial Insults and Free Speech Within the University" (1991) 79 Geo. L.J. 399 at 416. See also J.P. Byrne, "Academic Freedom: A Special Concem of the First Amendment" (1989) 99 Yale L.J. 251 at 334-34; J.P. Byme, "Academic Freedom and Political Neutrality in Law Schools; An Essay on Structure and Ideology in Professional Education" (1993) $43 \mathrm{~J}$. of Legal Ed. 315; M.A. Olivas, "Reflections on Professorial Academic Freedom: Second Thoughts on the Third 


\section{F. IS ACADEMIC FREEDOM A DEFENCE TO A HUMAN RIGHTS COMPLANNT?}

Having noted the seminal role of academic freedom in university scholarship and education, human rights statutes must be examined to determine whether such a defence can be advanced. The New Brunswick statute considered in Ross expressly provides that,

notwithstanding subsection (1), a limitation, specification, exclusion, denial or preference because of sex, physical disability or marital status shall be permitted if such limitation, specification, exclusion, denial or preference is based upon a bona fide qualification as determined by the Commission. ${ }^{164}$

Section $15(\mathrm{~g})$ of the C.H.R.A. also provides a defence to discrimination in the provision of services customarily available to the public if "there is bona fide justification for that denial or differentiation."165 Unfortunately, not all human rights statutes are consistent, and others would require individual analysis. ${ }^{166}$

\section{G. ANALYSIS OF A CLAIM OF ACADEMIC FREEDOM}

Once the complainant establishes a prima facie case of sexual harassment, the onus moves to the author of the impugned statements to establish academic freedom as a bona fide qualification or a bona fide justification. Characterization of the discrimination as having either a direct or adverse effect, in the case of poisoned

'Essential Freedom'" (1993) 45 Stanford L. Rev. 1835; W. P. Metzger, "Professional and Legal Limits to Academic Freedom" (1993) 20 J.C. \& U.L. 1.

Supra note 76, s. 5(2).

In Etobicoke, supra note 57 at 202, McIntyre J. held that, in an employment context, to constitute a bona fide occupational requirement (BFOR) or a bona fide occupational qualification (BFOQ), a limitation "must be imposed honestly, in good faith, and in the sincerely held belief that such a limitation is imposed in the interests of the adequate performance of the work involved with all reasonable dispatch, safety and economy, and not for ulterior or extraneous reasons aimed at objectives which could defeat the purpose of the [human rights statutes]."

In Manitoba, s. 13(1) of the Human Rights Code, supra note 86, provides for the defence of "bona fide and reasonable cause." Nova Scotia, in s. 6(f) of the Human Rights Act, supra note 86, provides a defence for bona fide qualification. In Alberta, the "bona fide occupational requirement" is restricted to employment in s. 7(3) of the Individual's Rights Protection Act, supra note 86, however, s. 11.1 provides a defence for all discrimination if the discrimination was "reasonable and justifiable." In Saskatchewan, the Human Rights Code, supra note 86, does not provide a comparable defence in the provision of public services, although s. 12(2) provides a defence for sex discrimination upon the ground of public decency, and s. 12(3) provides a defence for age if age laws are legislated. Ontario's Human Rights Code, supra note 86, is complex, in that it provides a defence of bona fide requirement or qualification for the case of constructive discrimination, in s. 11(1). Quebec does not provide a specific defence for public services, but does for other areas in $\mathbf{s} .20$ of their Charter, supra note 86. P.E.I. does not provide a bona fide qualification but does provide a BFOQ in s. 6(4) and has an age-related defence in s. 2(1) of the Human Rights Act, supra note 86 . Newfoundland provides a defence only for physical disability (Human Rights Code, supra note 86, s. 6(2)). 
environment, is particularly difficult. ${ }^{167}$ Assuming that academic freedom would constitute a defence, regardless of characterization, and given its integral nature to university education and scholarship, a factual analysis of the basis for the claim of academic freedom must be made. Such an inquiry must center on the bona fides of the academic and educational value of the impugned expression.

This position is consistent with the general principles governing research validity. Principles of research and scholarship prohibit fraud and misconduct in the research process. The core of academic freedom is an honest search for truth; the Policy Statement on Academic Freedom of C.A.U.T. states that the claim to academic freedom carries with it "the duty to use that freedom in a manner consistent with the scholarly obligation to base research and teaching on an honest search for knowledge."168

In the case of mathematics professor Yaqzan, the statement was not a bona fide scholarly work in his field of expertise. It could not be categorized as an "honest search for knowledge." Rather, it was a personal and biased opinion without evidentiary basis.

Clearly, the facts of the given case will be determinative. For example, direct, repetitive and unequivocal mysogynistic statements that create a poisoned educational environment cannot be upheld as an exercise of academic freedom or free expression, but constitute flagrant misconduct. Similarly, direct racial and gender-based slurs directed at particular students in the classroom by an educator cannot be upheld as legitimate exercises of academic freedom. ${ }^{169}$ Conversely, the creation of a poisoned work environment, through the publication of controversial but bona fide research findings regarding women, may constitute a factual defence within the confines of "academic freedom." In the cases of valid but unpopular scientific research, it could be argued that there has been an unreasonable violation of freedom of speech or academic freedom, in an effort to prevent dissemination of views inimical to sexual and racial

Once the complainant has established a prima facie case of discrimination, he or she is entitled to relief in the absence of justification by the respondent. Even if the respondent provides justification, it is open to the complainant to show that the explanation is pretextual. Once the complainant establishes a prima facie case, the onus then moves to the respondent to establish a BFOR or similar defence. In the case of employment, a distinction has been drawn between direct discrimination and adverse effect discrimination. Direct discrimination occurs where a practice or rule on its face discriminates on a prohibited ground, e.g. "No Catholics, no women and no blacks employed here." Adverse effect discrimination arises where a rule is neutral on its face but has an adverse effect on certain members of the group to whom it applies. In such a case, the appropriate response is to uphold the rule in its general application and consider whether the employer could have accommodated the employee adversely affected without undue hardship, which onus is on the respondent. See Central Alberta Dairy Pool v. Alberta (Human Rights Commission) (1990), 12 C.H.R.R. D/417 at D/433-34 (S.C.C.). Applebee's Food Conglomeration (1987), 9 C.H.R.R. D/4781 (Ont. Bd. Inq.) wherein the board found a violation under the Ontario Human Rights Code where racial slurs directed at others had been a major reason for the complainant leaving her employment. 
harmony. ${ }^{170}$ The central factor for analysis is the stringent scrutiny and assessment of the academic and research value of the impugned statements.

Factors for evaluating bona fides include: whether the expression was in the field of expertise of the author; whether the expression was based upon statistical evidence or other analysis of uncontroverted and complete facts, from which the premise was logically derived; whether the analysis involved complete and extensive research; whether the research was merely a guise to support the impugned expression. While this list is not exhaustive, a case-by-case analysis is more appropriate than defining a closed and inflexible list for such a complex evaluation.

\section{H. CHARTER ARGUMENTS}

While Ross sought to challenge the constitutionality of human rights codes in the context of a restriction of free speech in the school environment, universities could make analogous arguments founded upon academic freedom and free speech. Quite clearly, in the context of human rights proceedings, there would be a s. 2(b) violation in accordance with the stated reasoning of Taylor and Keegstra, and the comments of La Forest J. in McKinney:

Any attempt by government to influence university decisions, especially decisions regarding appointment, tenure and dismissal of academic staff, would be strenuously resisted by universities on the basis that this could lead to breaches of academic freedom. ${ }^{17}$

The $\mathrm{s} .1$ analysis has been discussed above in Ross. Of course, universities themselves are not bound by the Charter; e.g. students could not challenge university actions, such as a speech code, pursuant to $s$. 2 (b). ${ }^{172}$

\section{CONCLUSION}

The law in Canada is still developing as both courts and educational institutions attempt to grapple with striking the appropriate balance between free speech and proscription of sexual harassment. Free speech and academic freedom issues involve complex factual and legal analyses. The sexual harassment analysis requires

170 4.

171 Supra note 2 at $\mathrm{D} / 191$.

172 See McKinney, ibid. and Dickason, supra note 155. McKinney can be interpreted as signifying that Charter application, for universities, is restricted to the context of collective bargaining and tenure (academic freedom). See also s. 32 of the Charter, supra note 3. In the United States, state universities are viewed as state actors, while private universities are not: see Rendell-Baker $\mathbf{v}$. Kohn, 457 U.S. 830 at 839-43 (1982); and Krohn v. Harvard Law School, 552 F.2d 21 at 24 (1st. Cir. 1977), wherein the receipt of funds from the state did not ipso facto render the institutions "governmental bodies." In the context of public schools, colleges and hospitals, which are subject to the Charter, see Douglas/Kwantlen Faculty Assoc. v. Douglas College (1990), 13 C.H.R.R. D/403 (S.C.C.), wherein it was stated that the college was part of the government both in form and in fact, unlike universities, which though extensively regulated and funded by govemment, are essentially autonomous bodies. 
acknowledgment of the differing sensitivities and power relationships between men and women, the nature of human rights laws, standard and onus of proof, the definition of poisoned educational environment, and the standards of assessment (e.g. the "reasonable woman" standard, which should be expressly embraced by Canadian courts). The evaluation of free speech and academic defences is equally complex.

The forthcoming Supreme Court of Canada ruling in Ross will no doubt be of great assistance in evaluating these issues, both in the context of race and gender discrimination. It is hoped that legal arguments will be cognizant of the fact that while "[u]niversities comprise some of the outstanding research facilities that are essential to push forward the frontiers of knowledge," ${ }^{173}$ and the mandate to maintain academic excellence "is or should be the hallmark of a university," 174 universities must also meet their moral and legal commitments of creating and maintaining discrimination-free environments. "The university has three moral commitments that shape its activities: these are to the values of truth, humanism and democracy." ${ }^{175}$ 